NBER WORKING PAPER SERIES

\title{
ASSESSING HIGH HOUSE PRICES: \\ BUBBLES, FUNDAMENTALS \\ AND MISPERCEPTIONS
}

\author{
Charles Himmelberg \\ Christopher Mayer \\ Todd Sinai
}

Working Paper 11643

http://www.nber.org/papers/w11643

\author{
NATIONAL BUREAU OF ECONOMIC RESEARCH \\ 1050 Massachusetts Avenue \\ Cambridge, MA 02138 \\ September 2005
}

Himmelberg: Senior Economist, Research and Statistics Group, Federal Reserve Bank of New York (email: charles.himmelberg@ny.frb.org). Mayer: Paul Milstein Professor of Real Estate and Director of the Paul Milstein Center for Real Estate, Columbia Business School, Columbia University (email: cm310@columbia.edu). Sinai: Wharton School of the University of Pennsylvania (email: sinai@wharton.upenn.edu). A shorter version of this paper is forthcoming in the Fall, 2005 Journal of Economic Perspectives. The authors would like to especially thank Steven Kleiman and Reed Walker for extraordinary research support and Joseph Gyourko, James Hines, Steven Kleiman, Jonathan McCarthy, Richard Peach, Allen Sinai, Timothy Taylor, Michael Waldman, Neng Wang, and seminar participants at Columbia Business School for many helpful comments. The Paul Milstein Center for Real Estate at Columbia and the Zell/Lurie Real Estate Center at Wharton provided funding. The views expressed in the paper are solely those of the authors and do not necessarily reflect the position of the Federal Reserve Bank of New York or the Federal Reserve System. The views expressed herein are those of the author(s) and do not necessarily reflect the views of the National Bureau of Economic Research.

(C2005 by Charles Himmelberg, Christopher Mayer and Todd Sinai. All rights reserved. Short sections of text, not to exceed two paragraphs, may be quoted without explicit permission provided that full credit, including () notice, is given to the source. 
Assessing High House Prices: Bubbles, Fundamentals, and Misperceptions

Charles Himmelberg, Christopher Mayer and Todd Sinai

NBER Working Paper No. 11643

September 2005

JEL No. R21, R31, G10

\section{$\underline{\text { ABSTRACT }}$}

We construct measures of the annual cost of single-family housing for 46 metropolitan areas in the United States over the last 25 years and compare them with local rents and incomes as a way of judging the level of housing prices. Conventional metrics like the growth rate of house prices, the price-to-rent ratio, and the price-to-income ratio can be misleading because they fail to account both for the time series pattern of real long-term interest rates and predictable differences in the long-run growth rates of house prices across local markets. These factors are especially important in recent years because house prices are theoretically more sensitive to interest rates when rates are already low, and more sensitive still in those cities where the long-run rate of house price growth is high. During the 1980s, our measures show that houses looked most overvalued in many of the same cities that subsequently experienced the largest house price declines. We find that from the trough of 1995 to 2004 , the cost of owning rose somewhat relative to the cost of renting, but not, in most cities, to levels that made houses look overvalued.

Charles Himmelberg

Federal Reserve Bank of New York

33 Liberty Street

New York, NY 10045

charles.himmelberg@ny.frb.org

Christopher J. Mayer

Columbia Business School

3022 Broadway, Uris Hall \#808

New York, NY 10025

and NBER

cm310@columbia.edu
Todd M. Sinai

University of Pennsylvania, Wharton School 1465 Steinberg Hall - Dietrich Hall

3620 Locust Walk

Philadelphia, PA 19104-6302

and NBER

sinai@wharton.upenn.edu 


\section{Introduction}

House-price watching has become a national pastime. By 2004, 68 percent of households owned their own homes and, for most of them, housing equity will make up nearly all of their non-pension assets at retirement (Venti and Wise, 1991). Many of the 32 percent who rent are younger households, owners-in-waiting who watch housing markets with great interest (or concern). The preoccupation with housing markets has been particularly strong of late because recent house price growth has been rampant, especially in certain cities. Between 1975 and 1995, real single-family house prices in the United States increased an average of 0.5 percent per year, or 10 percent over the course of two decades. By contrast, from 1995 to 2004, national real house prices grew 3.6 percent per year, a more than seven-fold increase in the annual rate of real appreciation, and totaling nearly 40 percent in one decade. In some individual cities, such as San Francisco and Boston, real home prices grew about 75 percent from 1995 to 2004, almost double the national average.

How does one tell when rapid growth in house prices is caused by fundamental factors of supply and demand, and when it is an unsustainable bubble? Stiglitz (1990) provided a general definition of asset bubbles: "[I]f the reason that the price is high today is only because investors believe that the selling price is high tomorrow -- when 'fundamental' factors do not seem to justify such a price -- then a bubble exists. At least in the short run, the high price of the asset is merited, because it yields a return (capital gain plus dividend) equal to that on alternative assets." The "dividend" portion of the return from owning a house comes from the rent the owner saves by living in the house rent-free, and the capital gain from house price appreciation over time. We think of a housing bubble as being driven by home buyers who are willing to pay inflated prices for houses today because they expect unrealistically high housing appreciation in the future. ${ }^{1}$

In this paper, we explain how to assess the state of house prices - both whether there is a bubble, and what underlying factors support housing demand - in a way that is grounded in economic theory. In doing so, we correct four common fallacies about the costliness of the housing market. First, the price of a house is not the same as the annual cost of owning, so it does not necessarily follow from rising prices of houses that ownership is becoming more expensive. Second, high price growth is not evidence per se that housing is overvalued. In some local housing markets, house price growth can exceed the national average rate of appreciation for very long periods of time. Third, differences in expected appreciation rates and taxes can lead to considerable variability in the price-torent ratio across markets. Finally, the sensitivity of house prices to changes in fundamentals is higher at times when real, long-term interest rates are already low and in cities where expected price growth is high, so accelerating house price growth and outsized price increases in certain markets are not intrinsically signs of a bubble.

For all of the above reasons, conventional metrics for assessing pricing in the housing market such as price-to-rent ratios or price-to-income ratios generally fail to reflect

\footnotetext{
${ }^{1}$ Case and Shiller (2004) also use this definition.
} 
accurately the state of housing costs. To the eyes of analysts employing such measures, housing markets can appear "exuberant," even when houses are in fact reasonably priced.

We construct a measure for evaluating the cost of home owning that is standard for economists - the imputed annual rental cost of owning a home, a variant of the user cost of housing - and apply it to 25 years of history across a wide variety of housing markets. This calculation enables us to estimate the time pattern of housing costs within a market. Given the relatively short time series, it is hard to say just how costly a market must become before it is unsustainably expensive. However, we can determine how expensive a market is currently relative to its own history.

As of the end of 2004, our analysis reveals little evidence of a housing bubble. In highappreciation markets like San Francisco, Boston, and New York, current housing prices are not cheap, but our calculations do not reveal large price increases in excess of fundamentals. For such cities, expectations of outsized capital gains appear to play, at best, a very small role in single-family house prices. Rather, recent price growth is supported by basic economic factors such as low real, long-term interest rates, high income growth, and housing price levels that had fallen to unusually low levels during the mid-1990s. The growth in price-to-rent ratios - especially in cities where this ratio was already high - can be explained by the fact that house prices are more sensitive to real, long-term interest rates when interest rates are already low, and even more sensitive in cities where house price growth is typically high. During the late 1980s, our metrics indicate that house prices in many cities were, in fact, overvalued (e.g., Boston, Los Angeles, New York, and San Francisco), and prices in these cities subsequently fell. Thus, we do not find that housing prices are always close to equilibrium levels. Still, in 2004, prices looked reasonable. Only a few cities, such as Miami, Fort Lauderdale, Portland (Oregon), and to a degree, San Diego, had valuation ratios approaching those of the 1980s.

Of course, just because the data do not indicate bubbles in most cities in 2004 does not mean that prices cannot fall. Deterioration in underlying economic fundamentals, such as an unexpected future rise in real, long-term interest rates or a decline in economic growth, could easily cause a fall in house prices. Indeed, because real, long-term interest rates are currently so low, our calculations suggest that housing costs are more sensitive to changes in real, long-term interest rates now than any other time in the last 25 years. Finally, our data do not cover and hence do not allow us to comment on the condominium market, which due to its lower transaction costs and higher liquidity may be more vulnerable to overvaluation and overbuilding arising from investor speculation.

\section{How Not to Judge the Sustainability of Housing Prices}

To assess whether house prices are unsustainably high, casual observers often begin by looking at house price growth. Figure 1 shows that between 1980 and 2004, real house prices at the national level grew 39 percent, or 1.4 percent annually. To compute these numbers, we use data from the Office of Federal Housing Enterprise Oversight 
(OFHEO), which produces the most widely quoted single-family house price index. The OFHEO price index is based on multiple observations of the price of a given house, so unlike a conventional price index, it controls to some extent for the changing quality in the mix of houses sold at any given time, although changes in quality due to home renovations will not be normalized using this index. This housing price data is available for over 100 metropolitan areas since 1980. An index cannot be used to compare price levels across cities, but it can be used to calculate growth rates and to compare prices over time. The major drawbacks of this data are that it is subject to biases due to changes in the quality of existing houses, and it covers only those houses with so-called "conventional" mortgages that have been purchased by Fannie Mae and Freddie Mac. Since the current maximum lending limit for such mortgages in 2005 is $\$ 359,650$ for states in the continental United States, high-priced houses are underrepresented in the OFHEO index. ${ }^{2}$

Over the last quarter century, run-ups in house prices are common, but so are subsequent declines. The national average real house price fell by 7.2 percent from 1980 to 1982; rose by 16.2 percent from 1982 to 1989 ; fell by 8 percent from 1989 to 1995; and then rose by 40 percent from 1995 to 2004 . About one-third of the increase in real housing prices since 1995 reflects the return of house prices to their previous real peak of 1989 . Housing prices in 2004 have since risen to levels 29 percent over the previous 1989 peak. Of course, these summary descriptions and graphs of prices do not reveal whether fundamental factors or a price bubble are at work in the first half of the 2000s; we shall return to this question.

The national average masks considerable differences across metropolitan statistical areas. Table 1 presents index values that are standardized so that a value of 1.0 corresponds to the average, price level in a metropolitan statistical area over the 1980 to 2004 time period. We include all 46 metropolitan areas with available data on house price changes, rents, and per-capita income for the comparisons that follow. Over that time period, metro area house prices have followed one of three patterns. In about one-half of the cities, including Boston, New York, and San Francisco, house prices peaked in the late 1980 s, fell to a trough in the 1990s, and rebounded by 2004. Prices in 18 more metropolitan areas, including Miami and Denver, have a "U" shaped history: high in the early 1980s and high again by the end of the sample. A few cities, such as Houston and New Orleans, follow a third pattern; real house prices have declined since 1980 and have not fully recovered. The first three columns of Table 1 report the value of the house price index at three points in time: the most recent house price peak, the subsequent trough, and as of 2004.

Of the cities in the first category, a few have exhibited extraordinary appreciation since their mid-1990s trough. For example, by 2004 single-family house prices in Boston and seven California cities had risen more than 85 percent (adjusted for inflation), with San

\footnotetext{
${ }^{2}$ This is a potentially important caveat because markets for high-priced houses may behave differently. Mayer (1993), for example, shows that the prices of high-priced houses are more volatile than the values of lower-priced properties. The National Association of Realtors (NAR) produces an index that is not subject to the cap, but which does not control for changes in the mix of houses that sell over time. Our conclusions are unchanged if we use the NAR index for our analysis instead of the OFHEO index.
} 
Diego prices going up almost 120 percent to a level 83 percent above their 25 -year average. Much of this increase had merely offset prior house price declines, which were as much as 34 percent in Los Angeles and 25 percent or more in seven other cities (from peak to trough). But even relative to their prior peak house prices, most of these cities (excluding the two in Texas) have appreciated considerably. House prices in San Diego, Boston and New York, for example, were up 83, 38 and 22 percent above their respective prior peaks. ${ }^{3}$

Real house prices in the middle group -- for example, Austin, Cincinnati, Cleveland, Memphis, Kansas City, Pittsburgh, and St. Louis -- all exceeded their 25-year average by 2004, with Miami and Fort Lauderdale more than 50 percent above average. Real housing values in a few markets had even declined, as in Dallas, Fort Worth, Houston, New Orleans, San Antonio, with real annual house prices in Houston falling 1.2 percent a year, on average. (Figure 1 in the appendix plots house price indexes for all of the 46 MSAs in our data.)

A second commonly-cited measure used to assess housing valuations is the house priceto-rent ratio, which is akin to a price-to-earnings multiple for stocks. This metric is intended to reflect the relative cost of owning versus renting. Intuitively, when house prices are too high relative to rents, potential home buyers will choose instead to rent, thus reducing the demand for houses and bringing house prices back into line with rents. A common argument is that when price-to-rent ratios remain high for a prolonged period, it must be that prices are being sustained by unrealistic expectations of future price gains rather than the fundamental rental value, and hence contain a "bubble."

We obtained data on metro area rents between 1980 and 2004 from REIS, a real estate consulting firm. REIS provides annual average rents for a "representative" two-bedroom apartment in each metro area listed in Table 1. As with the OFHEO house price indexes, the rent data attempt to hold the quality of the rental unit constant over time. Again, we cannot compare rent levels across markets because our rent indices are not standardized to the same representative apartment across markets.. We can, however, construct a metro area index of real house prices relative to real rents and compare movements in this index over time. As before, we standardize the price-to-rent index so that a value of 1.0 corresponds to the average value between 1980 and 2004.

Figure 1 shows that, initially, the price-to-rent ratio closely tracked the overall house price movement. After 1989, the price-to-rent ratio slowly declined, reaching a trough in 2000. In the succeeding four years, the price-to-rent ratio grew 27 percent, leaving the ratio 15 percent above its previous peak (in 1989). By way of comparison, the prior trough-to-peak swing, from 1985 to 1989, was less than one-half the growth in the priceto-rent ratio from 2000-2004. The 1989 peak occurred right before a housing price decline, lending weight to the view that the price-to-rent ratio is an indicator of overheating in the housing market.

\footnotetext{
${ }^{3}$ House prices in these cities appear more volatile in booms and busts, a point emphasized by Case and Shiller (2004). We discuss this point in more detail, below.
} 
At the metropolitan statistical area level, many of the markets with a high growth rate of price-to-rent since their prior trough are the same markets that saw large price appreciation (for example, cities in California and the northeast). ${ }^{4}$ San Jose and Detroit experienced a doubling of their price-to-rent ratios since their prior troughs, and Portland, Oregon, experienced 95 percent growth.

More striking is the fact that the price-to-rent ratio in 2004 exceeds the 25 -year average everywhere except for four cities in Texas, and surpasses the prior peak in 80 percent of the cities. Column 6 (Table 1) shows the ratio of price-to-rent in 2004 relative to its average value from 1980-2004. In three of those cities, the price-to-rent ratio in 2004 exceeded its average value by more than 50 percent. San Francisco is only 14 percent above its prior peak, and New York is 12 percent below.

A third measure that is commonly used to assess whether housing prices are "too high" is the price-to-income ratio. Unlike the price-to-rent ratio, which measures the relative cost of owning and renting, the price-to-income ratio provides a measure of local housing costs relative to the local ability to pay.

Figure 1 shows the price-to-income ratio computed as the OFHEO price index divided by an index of median per-capita income based on data from the U.S. Bureau of Economic Analysis. At the national level, this ratio declined in the early 1980s, partially recovered to peak in 1987, and then declined again over the next decade, bottoming out 23 percent below its 1980 level. After 1998, the price-to-income ratio began to rise again, and by 2003 had exceeded its 1988 peak. Despite growing 21 percent over the last six years, it has not yet returned to its 1980 level. The decline in this ratio during most of the 1990s reveals that the growth in real house prices nationally was outpaced by the high growth in incomes (McCarthy and Peach, 2004).

At the metro area level, as shown in the last three columns in Table 1, price-to-income ratios have generally increased the most in cities where house price growth has been highest. Price-to-income is above its peak value in many of these cities (though not by nearly as much as the price-to-rent ratio), and as much as $40-50$ percent above its 25 -year average (the last column of Table 1). Yet there is a lot of heterogeneity in this measure of house price excess. In Houston, Dallas and other southern cities, price-to-income is well below its 25 -year average.

If high growth rates of house prices, price-to-rent ratios, and price-to-income ratios were reliable indicators of a rising cost of obtaining housing, then these recent trends would indeed provide reasons to suspect overvaluation in many housing markets. However, as this paper will explain, these measures are inadequate to assess whether the housing market is the grip of a speculative bubble.

\footnotetext{
${ }^{4}$ A few other markets such as Miami, Milwaukee, Minneapolis, and Portland saw their price-to-rent ratio rise by more than 50 percent. These all are markets that experienced economic declines in the 1970s and 1980 s, but have recovered appreciably since then.
} 


\section{The User Cost of Housing}

The key mistake committed by the conventional measures of overheating in housing markets is that they erroneously treat the purchase price of a house as if it were the same as the annual cost of owning. But consider purchasing a house for $\$ 1$ million. The cost of living in that house for one year is not $\$ 1$ million. Nor is the financial return on the house equal to just the capital gain or loss on that property. A correct calculation of the financial return associated with an owner-occupied property compares the value of living in that property for a year -- the "imputed rent", or what it would have cost to rent an equivalent property -- with the lost income that one would have received if the owner had invested the capital in an alternative investment -- the "opportunity cost of capital." This comparison should take into account differences in risk, tax benefits from owneroccupancy, property taxes, maintenance expenses, and any anticipated capital gains from owning the home.

This line of reasoning is the basis for an economically justified way of evaluating whether the level of housing prices is "too high" or "too low." We calculate the true oneyear cost of owning a house (the "user cost"), which can then be compared to rental costs or income levels to judge whether the cost of owning is out of line with the cost of renting, or unaffordable at local income levels. This section reviews the most commonly used procedure for calculating the annual cost of homeownership, discusses its implications for house prices, and then reviews the assumptions that enter the calculation. In this framework, a house price bubble occurs when homeowners have unreasonably high expectations about future capital gains, leading them to perceive their user cost to be lower than it actually is, and thus pay "too much" to purchase a house today.

\section{A Formula}

The formula for the annual cost of home ownership, also known in the housing literature as the "imputed rent," is the sum of six components representing both costs and offsetting benefits (Hendershott and Slemrod, 1983; Poterba, 1984). ${ }^{5}$ The first component is the cost of foregone interest that the homeowner could have earned by investing in something other than a house. This one-year cost is calculated as the price of housing $\mathrm{P}_{t}$ times the risk-free interest rate $r_{t}^{r f}$. The second component is the one-year cost of property taxes, calculated as house price times the property tax rate $\omega_{t}$. The third component is actually an offsetting benefit to owning, namely, the tax deductibility of mortgage interest and property taxes for filers who itemize on their federal income taxes. ${ }^{6}$ This can be estimated as the effective tax rate on income times the estimated mortgage

\footnotetext{
${ }^{5}$ These items should be viewed in opportunity cost terms. For example, an owner might make annual maintenance expenditures or else allow his home to slowly depreciate in value; either way, a cost is incurred.

${ }^{6}$ We use the mortgage rate when computing the tax benefit of owning a house as opposed to the Treasury rate used for the opportunity cost of capital. Mortgage rates are typically 1-2 percent above risk-free rates of equivalent duration because borrowers typically have the options to "refinance" if interest rates go down and to default on the mortgage if property prices fall. Homeowners can deduct from their taxable income the additional expense associated with both of these options, but they still receive their financial benefits. Thus, the U.S. government subsidizes the purchase of mortgages with prepayment and default options.
} 
and property tax payments: $\mathrm{P}_{\mathrm{t}} \tau_{\mathrm{t}}\left(\mathrm{r}_{\mathrm{t}}{ }^{\mathrm{m}}+\omega_{\mathrm{t}}\right){ }^{7} \quad$ The fourth term reflects maintenance costs expressed as a fraction $\delta_{t}$ of home value. Finally, the fifth term, $\mathrm{g}_{\mathrm{t}+1}$, is the expected capital gain (or loss) during the year, and the sixth term, $\mathrm{P}_{\mathrm{t}} \gamma_{t}$, represents an additional risk premium to compensate homeowners for the higher risk of owning vs. renting. The sum of these six components gives the total annual cost of home ownership:

Annual Cost of Ownership $=\mathrm{P}_{\mathrm{t}} \mathrm{r}_{\mathrm{t}}^{\mathrm{rf}}+\mathrm{P}_{\mathrm{t}} \omega_{\mathrm{t}}-\mathrm{P}_{\mathrm{t}} \tau_{t}\left(\mathrm{r}_{\mathrm{t}}^{\mathrm{m}}+\omega_{\mathrm{t}}\right)+\mathrm{P}_{\mathrm{t}} \delta_{\mathrm{t}}-\mathrm{P}_{\mathrm{t}} \mathrm{g}_{t+1}+\mathrm{P}_{\mathrm{t}} \gamma_{t}$

Equilibrium in the housing market implies that the expected annual cost of owning a house should not exceed the annual cost of renting. If annual ownership costs rise without a commensurate increase in rents, house prices must fall to convince potential home buyers to buy instead of renting. The converse happens if annual ownership costs fall. This naturally correcting process implies a "no arbitrage" condition which states that the one-year rent must equal the sum of the annual costs of owning. ${ }^{8}$ Using the above equation, we can summarize this logic by equating annual rent with the annual cost of ownership. We can re-arrange the annual cost of ownership by moving the price term in front of everything else on the right-hand side to get:

$\mathrm{R}_{\mathrm{t}}=\mathrm{P}_{\mathrm{t}} u_{\mathrm{t}}$

where the fraction $u_{\mathrm{t}}$ is known as the user cost of housing, defined as:

$\mathrm{u}_{\mathrm{t}}=\mathrm{r}_{\mathrm{t}}^{\mathrm{rf}}+\omega_{\mathrm{t}}-\tau_{\mathrm{t}}\left(\mathrm{r}_{\mathrm{t}}^{\mathrm{m}}+\omega_{\mathrm{t}}\right)+\delta_{\mathrm{t}}-\mathrm{g}_{\mathrm{t}+1}+\gamma_{\mathrm{t}}$

The user cost $u_{\text {it }}$ is just a restatement of the annual total cost of ownership defined above, but expressed in terms of the cost per dollar of house value. Expressing the user cost in this way is particularly useful because rearranging the equation $R_{t}=P_{t} u_{t}$ as $P_{t} / R_{t}=1 / u_{t}$ allows us to see that the equilibrium price-to-rent ratio should equal the inverse of the user cost. Thus, fluctuations in user costs (caused, for example, by changes in interest rates and taxes) lead to predictable changes in the price-to-rent ratio that reflect fundamentals, not bubbles. Comparing price-to-rent ratios over time without considering changes in user costs is obviously misleading.

\footnotetext{
${ }^{7}$ While it is widely recognized that mortgage payments are tax deductible, the equity-financed portion of a house is usually tax-subsidized as well. Owners do not pay income taxes on imputed rent (the money they "pay themselves" as owners of a property) or capital gains taxes for all but the largest gains. Under current tax law, gains from the sale of owner-occupied property (first and second homes) are free of taxation as long as the gain does not exceed $\$ 250,000$ for an individual or $\$ 500,000$ for a married couple and the owner has lived in the house two of the last five years. For a deeper analysis of the tax subsidy to owneroccupied housing, see Hendershott and Slemrod (1983) and Gyourko and Sinai (2003).

${ }^{8}$ Poterba (1984) writes the formula for the imputed rental value of housing as $R_{i t}=P_{i t}-\frac{1-\delta_{i t}}{1+r_{t}+\gamma_{i t}} E_{i t}\left[P_{i t+1}\right]+\left(1-\tau_{i t}\right) \omega_{i t} P_{i t}-\tau_{i t} r_{t} P_{i t}$.
}

The rental formula in the text is an approximation of this formula. 


\section{An Illustration}

For the purpose of illustrating how the user cost model works, suppose the following: (i) the risk-free 10-year interest rate $\mathrm{r}^{\mathrm{rf}}$ is 4.5 percent; (ii) the mortgage rate $\mathrm{r}^{\mathrm{m}}$ is 5.5 percent; (iii) the annual depreciation rate is $\delta=2.5$ percent (Harding, Rosenthal and Sirmans (2004); (iv) the marginal tax rate of the typical home buyer is $\tau=25$ percent; (v) the property tax rate is $\omega=1.5$ percent; (vi) the risk premium is $\gamma=2.0$ percent $^{9}$; and (vii) the long-run appreciation rate of housing prices is 3.8 percent (expected inflation of 2.0 percent plus a real expected appreciation rate of housing of 1.8 percent, the average from 1980-2004 for the metro areas in our sample for this paper).

Under these assumptions, the predicted user cost is 5.0 percent: that is, for every dollar of price, the owner pays 5 cents per year in cost. Leaving aside other differences between renting and owning, people should be willing to pay up to 20 times $(1 / 0.05)$ the market rent to purchase a house. ${ }^{10}$ Hence, for example, a two-bedroom apartment that rents for $\$ 1,000 /$ month $(\$ 12,000 /$ year) should sell for up to $\$ 240,000$. This price-to-rent ratio provides a ceiling against which housing prices can be judged "too high" or "too low." If price multiplied by the user cost exceeds the market rent, housing is relatively costly.

\section{House Prices are More Sensitive to Changes in Real Interest Rates When Rates are Already Low}

The real interest rate is a key determinant of the user cost of housing. (Below we explain why real long-term rather than short-term interest rates that are especially important). A lower real interest rate reduces the user cost because the cost of debt financing is lower, as is the opportunity cost of investing equity in a house. In practical terms, when the real interest rate is low, homeownership is relatively attractive because mortgage payments are low and alternative investments do not yield much. Given that mortgage interest is tax-deductible and the opportunity cost of the equity in the house is a taxable return, a percentage point decline in the real interest rate reduces the user cost by $1-\tau$. In our example, dropping the 10-year rate and mortgage rates from 4.5 and 5.5 percent to 4 and 5 percent, respectively, would cause the user cost to drop from 5 to 4.6 percent and cause the maximum price-to-rent multiple to rise from 20 to 21.9 .

Similarly, raising the income tax rate lowers the user cost of housing (Poterba, 1990), making housing less expensive than renting. In the above example, changing the assumed income tax rate from 25 percent to 35 percent in the base case example raises

\footnotetext{
${ }^{9}$ We obtain this estimated risk premium from Flavin and Yamashita (2002). This risk premium may be too high because it ignores important factors such as the insurance value of owning a house in hedging risk associated with future changes in rents. (Sinai and Souleles, 2005) However, choosing alternative values has little effect on the time series behavior of user costs, which is the focus of this paper. A more general model than ours would allow the relative risk of owning vs. renting to vary over time.

${ }^{10}$ They may not have to pay that amount. If housing is elastically supplied, and price is above the cost of construction, builders will create more housing at a lower multiple to rents.
} 
the sustainable price-to-rent ratio from 20 to $23.5 .^{11}$ The reason is that higher income taxes make the tax subsidy to owner-occupied housing worth more, which lowers the cost of housing relative to other goods.

It is apparent from these calculations that the lower the user cost, the higher the sensitivity of the rent multiple to changes in interest rates or the tax subsidy. For example, suppose real, one-year interest rates fall by one percentage point, or 0.75 percent after taxes. In a typical metropolitan area today with a 5 percent user cost, the user cost falls to 4.25 and the price-to-rent ratio could rise from 20 to 23.8, an increase of 19 percent. If the user cost were 7 percent, as it was at times during the early 1980 s, the same one percentage point decline in real interest rates would cause a smaller 12 percent rise in the justifiable price-to-rent ratio. Thus, in the current low real interest rate environment, a given decrease in real rates induces a larger potential percentage increase in house prices than the same decrease in real rates would cause starting from a high interest rate. Of course, the reverse is true, too: an unexpected rise in long-term real interest rates from their current low base would cause a disproportionately large percentage decline in the house price ceiling, assuming rents stay constant.

\section{House Prices are More Sensitive to Changes in Real Interest Rates in High Appreciation Rate Cities}

We have thus far downplayed one of the most critical and least understood determinants of the user cost of housing -- the expected growth rate of housing prices. Expected price appreciation is central to the debate over whether a housing bubble exists, and if so, where.

Evidence suggests that expected rates of house price appreciation may differ across markets. Because expected appreciation is subtracted from the user cost, metropolitan areas where expected house price appreciation is high have lower user costs than areas where expected house price appreciation is low. If in the above example we had assumed that the expected real rate of appreciation on housing was 2.8 percent rather than 1.8 percent, the predicted user cost would have been 4 percent instead of 5 , and the potential price-to-rent ratio would have been 25 instead of 20 . If we had assumed an even higher rate of expected price growth, say 3.8 percent, the implied price-to-rent ratio would have been 33.3. Lest this seem incredible, that is about equal to the price-to-rent ratio in the San Francisco metropolitan area, calculated as the ratio of the mean house value divided by the mean rent in the 2000 Census.

A large degree of variation across cities in expected growth rates is plausible, given what we know about land price dynamics in cities. Of course, if the long-run supply of housing were perfectly elastic, house prices would be determined solely by construction costs, and expected appreciation would be the expected growth rate in real construction

\footnotetext{
${ }^{11}$ Of course, this calculation does not account for the fact that higher taxes would presumably cause rents to fall, the net effect of which may or may not cause housing prices to fall. As Poterba (1990) explains, whether this happens or not depends on the extent to which the increased tax differential between and housing and non-housing causes consumers to choose more housing.
} 
costs (Muth, 1960). At the national level, real construction costs have fallen over the past 25 years, yet over the same time period, real constant-quality house prices have grown. When we looked at construction costs in different metropolitan areas using data from R.S. Means Company, ${ }^{12}$ we found that house prices grew relative to construction costs in most of the metropolitan statistical areas in our analysis. Changes in construction costs explain neither the overall rise in real house prices nor cross-sectional differences in appreciation rates across markets.

The long-run growth of house prices in excess of construction costs suggests that the underlying land is appreciating faster than the structures. This finding is consistent with classic theories of urban development in which the growth of cities is accompanied by (or driven by) benefits of increasing density and agglomeration. Since the supply of land near urban centers (either a city center or suburban subcenters) is in short supply, the demand for housing generated by such economic growth is capitalized into land prices. ${ }^{13}$

Indeed, some metropolitan areas have persistently high rates of house price appreciation over very long periods of time. Gyourko, Mayer, and Sinai (2004) refer to cities with high long-run rates of house price growth as "superstar cities." They argue that because of tight supply constraints combined with an increasing number of households who want to live in the area, a city can experience above-average house price growth over a very long horizon. They present evidence from the U.S. Census since 1940 showing that real house price appreciation in superstar cities such as San Francisco, Boston, New York, and Los Angeles has exceeded the national average by one to three percentage points per year over a 60 -year period. In addition, the average growth rate of housing prices over the 30-year period 1940-1970 has a correlation of 0.40 with the subsequent 30 -year average over 1970-2000. This fact suggests that differences in appreciation rates of housing across metropolitan statistical areas are persistent over long periods and reflect more than just secular changes in industrial concentration (like the high technology boom ) or household preferences.

A related finding is that price-to-rent differences across cities are persistent over time: cities with high price-to-rent ratios tend to remain high, and those with low price-to-rent ratio remain low. This fact is predicted by the user cost theory if purchasers in these "superstar" markets are correctly anticipating sustained future appreciation since buyers in superstar cities should be willing to pay more for a house if they expect rents to rise in the future. Indeed, Sinai and Souleles (2005) find statistical evidence using data from 44 metropolitan areas that the cities with the highest price-to-rent ratios also have the highest expected growth rates of prices and rents. ${ }^{14}$

\footnotetext{
${ }^{12}$ See Glaeser and Gyourko (2004) for more information on RS Means data and a detailed discussion of the issues involved in measuring construction costs across cities.

${ }^{13}$ See the Spring 1998 "Symposium on Urban Agglomeration" in the Journal of Economic Perspectives for more detail on these arguments, especially the papers by Edward Glaeser (1998) and John Quigley (1998).

${ }^{14}$ We have found a similar persistence of price-to-rent ratios across markets using data from the 1980 and 2000 Integrated Public Use Microsample from the U.S. Decennial Census to compute the price/income ratio at the household level for homeowners and the rent/income ratio at the household level for renters.
} 


\section{Calculating the User Cost}

To examine how these cost factors are related to house price changes, we compute the user cost of housing for each of the 46 metro areas in our sample. As is often true with theoretical constructs, solving for the user cost in practice poses a number of difficult challenges.

First, theory suggests that we measure the risk-free interest rate using a representative rate like the yield on a one-year U.S. Treasury bill. In practice, however, it is important to consider simultaneously the impact of expected future real interest rates on the expected appreciation rate of future house prices (the fifth term in our user cost equation). For example, in 2004, real short-term interest rates were well below real long-term rates, suggesting that the bond market anticipated that real short-term interest rates would rise in the future. When short-term rates are expected to rise, potential homeowners should also anticipate (assuming that land will be inelastically supplied in the market) that the annual cost of ownership will also rise, implying that future house prices should fall (or rise less than they otherwise would). Thus, a higher real interest rate "spread" -- the long-term minus short-term rate -- suggests a relatively lower expected growth rate of future house prices. This predictable decline in the future growth rate of house prices should roughly equal the spread. Hence, if we plug the spread into our user cost formula in place of $g_{t+1}$, the short-term rate drops out, and all that remains is the long-term rate. In sum, when a constant rate of future price appreciation is assumed for the user cost formula, it is probably more sensible to measure the opportunity cost of funds using a real, long-term interest rate. This subtle point is often ignored in empirical research. In our calculations below, we use the constant yield to maturity on 10-year Treasuries and convert this to a real rate by subtracting the 10 -year expected inflation rate from the Livingston Survey. If we were to substitute the one-year Treasury rate into our user cost calculations instead of the 10-year rate, it would make housing in 2004 look even less costly in every market in our sample.

A second, closely related challenge is that we cannot observe households' expected growth rate of housing prices. By using long-term instead of short-term real interest rates in the user cost, we already account for predictable changes in house prices arising from predictable changes in short-term interest rates. But house prices also rise in response to higher rents. We assume that user costs do not change over long horizons, and that hence rents at the level of a metropolitan area grow at the same rate as real housing prices in that metro area. We therefore measure expected future rent growth using the average real growth rate of house prices from 1940-2000 from Gyourko, Mayer, and Sinai (2004).

Finally, it is important to recognize that metro areas also differ in their typical federal income taxes and local property tax rates. Cities with higher per-capita income have higher effective marginal income tax rates, which lead to higher price-to-rent ratios due to the greater value of the tax subsidy to owner-occupied housing. We use average property tax rates from Emrath (2002) and income tax rates which we collect from the

We then took the average of each ratio by metropolitan statistical area and decade. Price-to-rent at the metropolitan area -decade level is then calculated as MEAN(price/income)/MEAN(rent/income). 
TAXSIM model of the National Bureau of Economic Research. ${ }^{15}$ However, data from the Internal Revenue Service shows that 65 percent of tax-filing households do not itemize their tax deductions and, if they are homeowners, do not benefit from the tax deductibility of mortgage interest and property taxes. ${ }^{16}$ To account at least roughly for the higher cost of owning for the non-itemizers, we reduce the tax subsidy in our calculations by 50 percent.

Table 2 shows how user cost can vary across cities and within cities over time. The average user costs in the highest growth rate markets are less than half as big as they are in the highest user cost markets - for example, 3.3 percent in San Jose vs. 7.1 percent in Pittsburgh. This range of user costs implies average potential price-to-rent ratios ranging from 33 to 14, respectively. By 2004, user costs had fallen significantly below the longrun average - 2.0 percent in San Jose versus 5.7 percent in Pittsburgh. That is, the priceto-rent ratio could have risen to 50 in San Jose but just 18 in Pittsburgh. To illustrate how much a low initial user cost matters for price swings, San Francisco experienced a user cost decline from an average of 3.7 percent to 2.4 percent in 2004, implying a multiple expansion from 27 to 42 . In some cities, user cost has declined more than 40 percent since the previous house price peak, while in other cities the decline has been as low as 10 percent. Since the user cost is just the inverse of the price-to-rent ratio, these examples demonstrate how heterogeneous changes in user cost can help explain the heterogeneity of price and price-to-rent growth across cities. More formally, the crosssectional correlation between the percentage change in user costs (the second column of Table 2) and the percentage change in price-to-rent (the third column of Table 1) between 1995 and 2004 is -0.6 .

Finally, it is worth noting that these computations do not account for all factors that could affect the spread in user costs between high and low appreciation rate cities. In highpriced cities, the value of structures is generally small relative to the value of the land on which they sit, which suggests that physical depreciation is small as a fraction of total property value. Lower depreciation rates (relative to value) in high land cost markets such as San Francisco and New York would lower their user costs and further increase their price-to-rent ratios relative to other cities. Our calculations do not allow for this.

At the same time, lower depreciation rates in cities like San Francisco might be offset by higher house price risk. Some research has argued that housing in high-priced cities is riskier because the standard deviation of house prices is much higher (Case and Shiller 2004; Hwang and Quigley, 2004), while other research argues that homeowners can

\footnotetext{
${ }^{15}$ While the net benefits of services financed by local property taxes presumably benefit owners and renters equally, a higher property tax nevertheless lowers the price-to-rent ratio because the tax is implicitly included in rents but not home prices.

${ }^{16}$ Sources: IRS Statistics of Income, Table 1 -- Individual Income Tax, All Returns: Sources of Income and Adjustments, and Table 3 -- Individual Income Tax Returns with Itemized Deductions, for 2002. Available at $<$ http://www.irs.gov/pub/irs-soi/02in01ar.xls $>$ and $<$ http://www.irs.gov/pub/irs-soi/02in03ga.xls $>$. Even without itemizing, all homeowners benefit from some tax subsidy. If a homeowner were to rent his property out, he would have to report the rent received as taxable income. A homeowner does not need to report the "imputed rent" he pays himself as taxable income and thus saves the income tax he would have otherwise paid the government. Gyourko and Sinai (2003) show that the mortgage interest and property tax deduction component comprises about one-third of the total subsidy.
} 
partially hedge this rent and price risk (Sinai and Souleles, 2005). ${ }^{17}$ Since this hedge is imperfect, however, we would still expect risk premiums would be somewhat higher in the highest price-to-rent markets, narrowing the predicted cross-sectional difference in user costs between cities like San Francisco and Milwaukee, say. Our calculations do not allow for this effect, either.

\section{Are Current House Prices Too High?}

One way to assess whether house prices are too high is to calculate the imputed rent on housing and compare it to actual rents available in the market. The imputed rent is the user cost times the current level of house prices obtained from the OFHEO price index.

We create an index of the imputed-to-actual-rent ratio by dividing the imputed rent index by the index of market rents. This index lets us assess whether the imputed cost of owning a house relative to renting the same unit has changed within each metropolitan area over time and whether the index in 2004 is at or near its previous peak level. We cannot make comparisons of imputed-to-actual-rent levels across cities, nor can we explicitly calculate whether the index is "too high" at any given point in time, but we can come close by comparing the index to its 25 -year average.

We set the within-city 25-year average of the index equal to 1.0 in each city. Figure 2 plots the imputed-to-actual-rent index for 12 representative cities. (Figure 2 in the appendix plots house price indexes for all 46 MSAs in our data.) We also include the equivalent price-to-rent index for these cities to highlight the times that the price-to-rent index differs from the imputed-to-actual-rent ratio. In Figure 2, Houston represents the small group of cities that have been experiencing declining prices and imputed rent ratios over 25 years. Chicago, Detroit, Miami, and Indianapolis are indicative of the middle panel cities that have U-shaped prices and imputed rent ratios. The remaining cities are representative of the cyclical first panel and include some of the highest profile markets on the east and west coasts. Table 3 reports the value of the imputed-to-actual-rent index for all 46 cities at some key dates.

We highlight two important results. First, the imputed-to-actual-rent ratio does not suggest widespread or historically large mispricing of owner-occupied properties in 2004. For all three groups of cities, the imputed rent associated with buying a house in 2004 is not nearly as high relative to actual rents as it was in the past. Only seven cities have an imputed-to-actual-rent ratio that is within 20 percent of its previous peak and, of those, Detroit, Milwaukee, and Minneapolis are the closest. By contrast, 12 cities have imputed-to-actual-rent ratios 40 percent or more below their historical peak levels. In fact, the 2004 levels of imputed-to-actual-rent are hardly atypical. In Portland, Oregon, the 2004 imputed-to-actual-rent ratio exceeds the value of the ratio in prior years about

\footnotetext{
${ }^{17}$ Davidoff (2005) shows that the demand for owned housing decreases as the covariance between labor income and house prices rises. By that logic, the price-to-rent ratio also should be lower in markets where the typical homebuyer's wage income is closely tied to the local economy -- in one-company towns, for instance, or cities with a high concentration in a single industry.
} 
75 percent of the time (88 percent in Detroit). But in high price growth cities like Orange County and San Francisco, the imputed-to-actual-rent ratio in the previous 24 years was higher than its 2004 value about half the time. While owner-occupied housing is not nearly as expensive relative to renting as it has been at times over the past 24 years, housing in a few markets appears somewhat expensive relative to the recent past.

A second key observation is that deviations between the imputed rent and actual rent appear strongest when real interest rates were unusually high (early 1980s) or unusually low (2001-2004). A comparison of Figures 2 and 3 makes this point quite clear. Another, unrelated factor that explains the strong 1980s deviation was that the U.S. tax code subsidized the construction of rental properties between 1981 and 1987, leading to a decline in rents and temporarily out-of-equilibrium price-to-rent ratios. Thus the recent run-up in house prices appears to be primarily driven by fundamental economic changes. Of course, in Boston, New York, Los Angeles, San Diego and San Francisco in the late 1980s and Denver, Miami, and Houston in the mid-1980s, a high imputed-to-actual-rent ratio was a prelude to sizable housing downturns. Hence, our methodology successfully identifies prior periods of excessive valuations in the housing market.

The imputed rent-to-income ratio provides an alternative measure of housing valuations. While the imputed-to-actual-rent ratio would be high if there were a housing bubble, house prices could still fall if current housing costs were unsustainable given households' abilities to pay. The ratio of imputed rent to income provides a better indicator of whether house prices are supported by underlying demand. In particular, rising housing prices or rising user costs need not imply that households are being priced out of the market if incomes are rising, too. In a bubble market, by contrast, we would expect to see the annual cost of homeownership rising faster than incomes, thus raising imputed rentto-income to unsustainable levels.

Figure 4 reports the ratio of the imputed rent of owner-occupied housing to income for 12 cities, with a matching panel in Table 3 . (Figure 3 in the appendix plots house price indexes for all 46 MSAs in our data.) For comparison, Figure 4 also shows the morecommonly used metric of house price-to-income. These ratios were calculated in the same way as the imputed-to-actual-rent ratio, except that we now divide imputed rent by an index of mean income per capita at the level of the metropolitan statistical area constructed from BEA data. We set the index value of 1.0 to correspond to the 25-year average for each metropolitan area of each ratio.

These calculations lead us to similar conclusions as in the previous section. None of the metropolitan areas that we have featured appears to be at a peak level of costliness in 2004 (relative to the past 25 years). In fact, only nine of our 46 cities have housing costs above their average historical levels relative to per capita income. Even so, the range across cities in the 2004 imputed rent-to-income measure, which varies from 1.12 in Miami to 0.62 in San Antonio, is much tighter than the within-city variation over time. Indeed, in Miami, the imputed rent-to-income ratio has a historical peak-trough range of more than 50 percent. One might object to these historical comparisons on the grounds that prices during the 1980s were unusually higher. If remove the 1980s data, it is still the case that only southern California and south Florida look relatively expensive. 
Outliers for the ratios of imputed-rent-to-income or price-to-income are most pronounced in years when real interest rates are historically high or historically low. Just as with our imputed-to-actual-rent ratio, a high imputed-rent-to-income ratio has been a prelude to subsequent price declines. Despite having been corrected to recognize differences in user costs, the imputed rent-to-income ratio comes with an important caveat. Households at the median income may be poorer than the marginal buyers of median-priced homes. For example, Gyourko, Mayer, and Sinai (2004) argue that the marginal home buyers in "superstar" cities are high-income households who have moved from other parts of the country. This pattern would imply that the median homes in such cities are purchased by new residents whose income exceeds that of the median income. Also, Ortalo-Magne and Rady (2005) argue that homeowners whose incomes do not grow as fast as house prices in an area can remain homeowners since their housing wealth rises commensurately with prices. Thus they can appear to be low-income, but that is because the implicit income from their housing wealth is not reflected in the denominator of the imputed rent-to-income ratio. For these reasons, our measure of the imputed rent-toincome ratio in high price growth markets is likely to be higher than the true underlying concept. Ideally, we would also want to consider wealth ratios when assessing the extent of housing market excess.

But even given this caveat, housing prices at the end of 2004 did not look particularly out of line with past patterns of rents or incomes. This conclusion holds true even in cities like Boston, New York, and San Francisco where housing prices were high and rose even higher from 2000 to 2004. Only a handful of cities, namely Miami, Fort Lauderdale, Portland, and San Diego, had imputed-to-actual-rent and imputed rent-to-income ratios that both were higher relative to the recent past, but even they had not yet risen to approach previous historical peak levels.

\section{What Might Be Missing in these Calculations?}

One obviously important factor over the past 25 years that we have omitted from our analysis is cost-reducing innovations in the mortgage market. Data from the Federal Housing Finance Board suggests that in 1980, initial fees and "points" (a point is an upfront fee equal to one percent of the loan amount) were typically about 2 percent of the value of a loan; by 2004, they were less than one-half of 1 percent. Lower origination costs may be a factor in the greater willingness of homeowners to refinance their mortgage in response to decreases in interest rates (Bennett, Peach and Peristiani, 1998). Since lower origination costs are likely a permanent change in the mortgage market, demand for housing may be permanently higher, lowering the imputed rent associated with owning a house in the latter portion of our sample period.

An alternative hypothesis sometimes advanced for the recent rapid growth in housing prices is that it has become easier to borrow, so that overall demand for home-owning has risen. Certainly average mortgage amounts have risen much faster than inflation or incomes, growing by over $\$ 120,000$ since 1995 to a record high of over $\$ 261,000$ in 2003. Yet average down payments amounts have grown even faster. The average new 
first mortgage in 2003 had a down payment that exceeded 25 percent of the house value, nearly five percentage points higher than in 1995. Lest one fear that these aggregate statistics mask a number of liquidity constrained households, the percentage of household with a loan-to-value ratio at or above 90 percent fell from 25 percent to 20 percent of all borrowers between 1997 and 2003. In addition, down payment percentages are the highest (and thus loan-to-value ratios are lowest) in the most expensive cities. Down payments for buyers in San Francisco and New York averaged 39 and 34 percent of their house value, respectively. We suspect that this occurs in part because existing homeowners use large capital gains to put more money down on their next house. One caveat: if homeowners are extracting equity using second mortgages, and doing so disproportionately in the most expensive cities, our data would underestimate their true leverage. However, it would take considerable borrowing through that channel to offset the increase in down payments we observe.

A related concern is that if many people have borrowed using adjustable rate mortgages, they may be especially vulnerable to an in increase in interest rates. From 2001-2003, adjustable rate mortgages made up fewer than 20 percent of all new mortgages, a rate that is lower than all but one year in the 1990s. However, the use of adjustable rate mortgages did rise to 34 percent of new mortgages in 2004. While buyers in high-priced cities are more likely than average to take out adjustable rate mortgages, the use of adjustable rate mortgages also fell disproportionately in the most expensive cities, with declines from 1995-2003 of 21 and 16 percent in San Francisco and New York, respectively (the decline in Boston was smaller).

Even so, if any of the above considerations were actually spurring spending in the housing market, our analysis should pick it up as more costly homeownership. Demand driven by looser restrictions on obtaining credit, for example, should lead to higher house prices. In our analysis, the higher price would raise the imputed rent, and the imputed-toactual-rent and imputed rent-to-income ratios would rise. We do not observe this, at least by the end of 2004. The last time such factors (anecdotally, at least) affected the housing market was in the late $1980 \mathrm{~s}$, and that mispricing is very apparent in our data.

Yet another potential shortcoming of our analysis is that we assume low-cost arbitrage between owning and renting. In reality, mortgage origination fees, broker commissions and moving costs make it expensive to switch back and forth between owning and renting. These transaction costs imply a range within which imputed rents may deviate from actual rents before market forces work to close the gap. Arbitrage arguments may also fail because the characteristics of rental units and owned homes may differ substantially, in which case imputed rent comparisons are less meaningful.

Finally, our valuation ratios may be biased due to trends in unmeasured quality differences between owned and rented units. We have no reason to believe that the quality of owner-occupied housing has systematically declined relative to that of rental housing. If anything, the reverse is likely true due to the strong growth in home renovation expenditures. If the quality of existing single-family homes is rising, the OFHEO price index might overstate housing appreciation rates for a constant quality house. 


\section{Conclusion}

We have discussed how to calculate the local annual cost of owner-occupied housing and how to construct measures of home values by comparing this cost to local incomes and rents. Doing so reveals past periods like the late 1980s when the costs of owning looked quite high relative to incomes or the cost of renting. In 2004, however, these same measures show little evidence of housing bubbles in almost any of the markets we have studied. Constant-quality data on house prices and rents exist for less than three decades, cover only two house price booms, and are not comparable across different cities. Hence, it is impossible to state definitively whether or not a housing bubble exists. However, we can say that most housing markets did not look much more expensive in 2004 than they looked over the past 10 years, and in most major cities our valuation measures are nowhere near their historic highs.

We hope the following insights emerge from our analysis: First, house price dynamics are a local phenomenon, and national-level data obscure important economic differences among cities. Moreover, one cannot draw conclusions about house prices by comparing cities: price-to-income and price-to-rent ratios that would be considered "high" for one city may be typical for another. Second, when considering local house prices, the economically relevant basis for comparison is the annual cost of ownership. Without accounting for changes in real, long-term interest rates, expected inflation, expected house price appreciation and taxes, one cannot accurately assess whether houses are reasonably priced. Third, changes in underlying fundamentals can affect cities differently. In particular, in cities where housing supply is relatively inelastic, prices will be higher relative to rents, and house prices will typically be more sensitive to changes in interest rates.

Our evidence does not suggest that house prices cannot fall in the future if fundamental factors change. An unexpected rise in real interest rates that raises housing costs, or a negative shock to a local economy, would lower housing demand, slowing the growth of house prices, and possibly even leading to a house price decline. However, this fact does not mean that today houses are systematically mispriced. 


\section{References}

Ayuso, Juan and Fernando Restoy (2003), "House Prices and Rents: An Equilibrium Approach," working paper no.0304, Banco de España.

Bennett, Paul, Richard Peach, and Stavros Peristiani (1998). "Structural Change in the Mortgage Market and the Propensity to Refinance," Federal Reserve Band of New York Staff Reports, 45, September.

Brueckner, Jan K (1987). "The Structure of Urban Equilibria: A Unified Treatment of the Muth-Mills Model," in Edwin S. Mills, ed., Handbook of Regional and Urban Economics, 2, North Holland, pp. 821-845.

Case, Karl E. and Robert J. Shiller (1988), "The Behavior of Home Prices in Boom and Post-Boom Markets", New England Economic Review, November, pp. 29-46. (1989) "The Efficiency of the Market for Single Family Homes", American Economic Review (March 1989), 79(1): 125-37.

(2004), "Is There a Bubble in the Housing Market", Brookings Papers on Economic Activity, 2, 299-342.

Cocco, Joao (2000), “Hedging House Price Risk with Incomplete Markets," London Business School working paper.

Cocco, Joao F. and John F. Campbell (2003), "Household Risk Management and Optimal Mortgage Choice," Quarterly Journal of Economics, November, 1449-1494.

Davidoff, Thomas (2003), “Labor Income, Housing Prices and Homeownership,” UC Berkeley mimeo.

Emrath, Paul. "Property Taxes in the 2000 Census," Housing Economics, 2002 (December), 16-21.

Engelhardt, Gary (1994), "House Prices and the Decision to Save for Down Payments," Journal of Urban Economics 36:2 (September), 209-237.

Engelhardt, Gary (1996), "Consumption, Down Payments, and Liquidity Constraints," Journal of Money, Credit, and Banking 28:2 (May), 255-271.

Flavin, Marjorie and Takashi Yamashita (2002), "Owner-Occupied Housing and the Composition of the Household Portfolio." American Economic Review, March, 345-62.

Genesove, David and Christopher Mayer (1997). "Equity and Time to Sale in the Real Estate Market." The American Economic Review 87(3), 255-69. 
(2001). "Loss Aversion and Seller Behavior: Evidence from the Housing Market." Quarterly Journal of Economics 116(4), 1233-1260.

Glaeser, Edward L. (1998), “Are Cities Dying?," Journal of Economic Perspectives 12(2), 139-60.

Glaeser, Edward L. and Joseph Gyourko (2005), "Durable Housing and Urban Decline," Journal of Political Economy 113(2), 345-75.

Glaeser, Edward L., Joseph Gyourko, and Raven E. Saks (2004), "Why Have Housing Prices Gone Up?” working paper.

Glaeser, Edward L. and Albert Saiz (2003), "The Rise of the Skilled City,” NBER Working Paper 10191.

Gyourko, Joseph, Christopher Mayer, and Todd Sinai (2004), "Superstar Cities", Columbia Business School and Wharton School working paper.

Gyourko, Joseph and Todd Sinai (2003). "The Spatial Distribution of Housing-Related Ordinary Income Tax Benefits.” Real Estate Economics, vol. 31, number 4 (Winter), pp. 527-576.

Hanushek, Eric A. and John M. Quigley (1980). "What is the Price Elasticity of Housing Demand?" Review of Economics and Statistics 62(3), pp. 449-54.

Harding, John P., Stuart S. Rosenthal and C. F. Sirmans (2004), "Depreciation of Housing Capital and the Gains from Homeownership," working paper, Syracuse University, http://faculty.maxwell.syr.edu/rosenthal.

Hendershott, Patric and Joel Slemrod (1983). "Taxes and the User Cost of Capital for Owner-Occupied Housing," AREUEA Journal, Winter, 10 (4), 375-393.

Henderson, J. V. (1977), Economic Theory and the Cities, New York: Academic Press.

Hurst, Erik and Frank Stafford (2005), "Home is Where the Equity Is: Liquidity Constraints, Refinancing and Consumption", Journal of Money, Credit and Banking, forthcoming.

Hwang, Min and John M. Quigley (2004), Economic Fundamentals in Local Housing Markets: Evidence from U.S. Metropolitan Regions, UC Berkeley mimeo, February.

Lamont, Owen and Jeremy Stein (1999), "Leverage and House Price Dynamics in U.S. Cities", Rand Journal of Economics 30, Autumn, pp. 466-486. 
Mayer, Christopher (1993). "Taxes, Income Distribution and the Real Estate Cycle: Why All Houses Don't Appreciate at the Same Rate." New England Economic Review, May/June, 39-50.

Meese, Richard and Nancy Wallace (1993). Testing the Present Value Relation for Housing Prices: Should I Leave My House in San Francisco? Journal of Urban Economics 35(3), 245-66.

Mayo, Stephen (1981). "Theory and Estimation in the Economics of Housing Demand." Journal of Urban Economics 10, pp. 95-116.

McCarthy, Jonathan and Richard W. Peach (2004). “Are Home Prices the Next Bubble?" Federal Reserve Bank of New York Economic Policy Review 10(3), pp. 1-17.

Merlo, Antonio and Francois Ortalo-Magne (2004). "Bargaining over Residential Properties: Evidence from England," Journal of Urban Economics 56, September, 192-216.

Moretti, Enrico (2004). “Workers' Education, Spillovers and Productivity: Evidence from Plant-Level Production Functions," American Economic Review, 94(3), pp. 656690.

Muth, R. F. (1960), "The Demand for Nonfarm Housing," in A. C. Harberger, ed., The Demand for Durable Goods. Chicago: University of Chicago Press.

(1969), Cities and Housing. Chicago: University of Chicago Press.

Ortalo-Magne, Francois and Sven Rady (1999). "Boom in, Bust Out: Young Households and the Housing Cycle," European Economic Review 43, April, 755-766.

(2001). "Housing Market Dynamics: On the Contribution of Income Shocks and Credit Constraints," Discussion Paper 470, CESIfo.

Piazzesi, Monika, Martin Schneider, and Selale Tuzel (2003), "Housing, Consumption and Asset Pricing," working paper.

Poterba, James (1984), “Tax Subsidies to Owner-occupied Housing: An Asset Market Approach," Quarterly Journal of Economics 99, 729-52.

(1990). "House Price Dynamics: The Role of Tax Policy and Demography" Brookings Papers on Economic Activity 1991(2), pp. 143-183.

Quigley, John M. (1998), "Urban Diversity and Economic Growth,” Journal of Economic Perspectives 12(2), 127-38. 
Rosenthal, Stuart S. and William C. Strange, "Evidence on the Nature and Sources of Agglomeration Economies," in J.V. Henderson and J.-F. Thisse, eds., Handbook of Urban and Regional Economics, Volume 4 (Amsterdam: Elsevier), 2004, 2119-2172.

Shiller, Robert J. (1993), Macro Markets: Creating Institutions for Managing Society's Largest Economic Risks, Oxford University Press.

Sinai, Todd and Nicholas Souleles (2005). "Owner Occupied Housing as a Hedge Against Rent Risk," Quarterly Journal of Economics, May.

Stiglitz, Joseph E. (1990). "Symposium on Bubbles," Journal of Economic Perspectives 4(2), Spring, pp. 13-18.

Stein, Jeremy (1995). "Prices and Trading Volume in the Housing Market: A Model with Downpayment Effects," Quarterly Journal of Economics 110, May, pp. 379-406.

Terrones, Marcos (2004). "The Global House Price Boom" in The World Economic Outlook: The Global Demographic Transition Chapter 2 (Three Current Policy Issues), pp. 71-89.

Venti, Steven and David Wise (1991). "Aging and the Income Value of Housing Wealth,” Journal of Public Economics (44), pp. 371-397. 


\section{Table 1}

\section{Conventional Measures of House Price Dynamics}

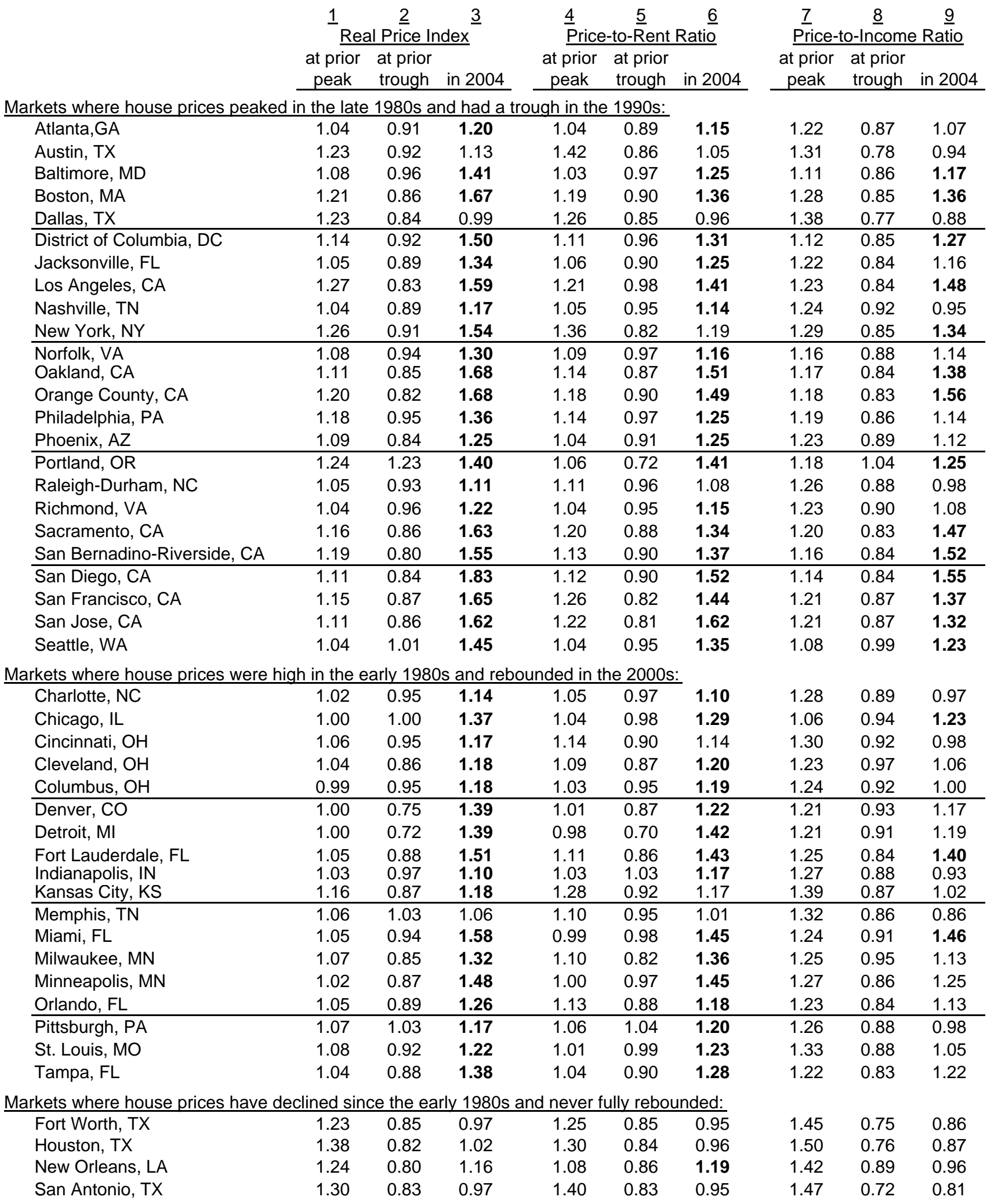

Notes: 24-year within-MSA average is normalized to 1.00. Values are not comparable across markets.

2004 figures are in bold when they exceed their prior peak values. 


\section{Table 2 \\ How User Cost Varies Across Cities and Over Time \\ Average $\underline{2}$ user cost \\ User cost $\%$ change in user cost since $\%$ change in}

Markets where house prices peaked in the late 1980s and had a trough in the 1990s:

\begin{tabular}{|c|c|c|c|c|}
\hline Atlanta,GA & $5.3 \%$ & $3.9 \%$ & $-31 \%$ & $-26 \%$ \\
\hline Austin, TX & $6.0 \%$ & $4.5 \%$ & $-42 \%$ & $-22 \%$ \\
\hline Baltimore, MD & $5.7 \%$ & $4.3 \%$ & $-29 \%$ & $-22 \%$ \\
\hline Boston, MA & $5.3 \%$ & $4.0 \%$ & $-34 \%$ & $-21 \%$ \\
\hline Dallas, TX & $6.4 \%$ & $4.9 \%$ & $-17 \%$ & $-18 \%$ \\
\hline District of Columbia, DC & $5.6 \%$ & $4.4 \%$ & $-28 \%$ & $-22 \%$ \\
\hline Jacksonville, FL & $4.9 \%$ & $3.4 \%$ & $-23 \%$ & $-25 \%$ \\
\hline Los Angeles, CA & $4.4 \%$ & $3.1 \%$ & $-38 \%$ & $-27 \%$ \\
\hline Nashville, TX & $5.5 \%$ & $4.0 \%$ & $-31 \%$ & $-21 \%$ \\
\hline New York, NY & $6.0 \%$ & $4.8 \%$ & $-29 \%$ & $-20 \%$ \\
\hline Norfolk, VA & $5.6 \%$ & $4.2 \%$ & $-33 \%$ & $-23 \%$ \\
\hline Oakland, CA & $4.2 \%$ & $2.9 \%$ & $-39 \%$ & $-30 \%$ \\
\hline Orange County, CA & $3.7 \%$ & $2.5 \%$ & $-41 \%$ & $-33 \%$ \\
\hline Philadelphia, PA & $6.6 \%$ & $5.2 \%$ & $-27 \%$ & $-19 \%$ \\
\hline Phoenix, AZ & $4.7 \%$ & $3.3 \%$ & $-23 \%$ & $-6 \%$ \\
\hline Portland, OR & $6.0 \%$ & $4.7 \%$ & $-11 \%$ & $-20 \%$ \\
\hline Raleigh-Durham, NC & $5.2 \%$ & $3.8 \%$ & $-19 \%$ & $-20 \%$ \\
\hline Richmond, VA & $6.1 \%$ & $4.7 \%$ & $-27 \%$ & $-21 \%$ \\
\hline Sacramento, CA & $4.7 \%$ & $3.5 \%$ & $-28 \%$ & $-25 \%$ \\
\hline San Bernadino-Riverside, CA & $4.6 \%$ & $3.3 \%$ & $-36 \%$ & $-26 \%$ \\
\hline San Diego, CA & $4.1 \%$ & $2.9 \%$ & $-40 \%$ & $-30 \%$ \\
\hline San Francisco, CA & $3.7 \%$ & $2.4 \%$ & $-41 \%$ & $-34 \%$ \\
\hline San Jose, CA & $3.3 \%$ & $2.0 \%$ & $-46 \%$ & $-33 \%$ \\
\hline Seattle, WA & $4.9 \%$ & $3.4 \%$ & $-38 \%$ & $-25 \%$ \\
\hline \multicolumn{5}{|c|}{ rkets where house prices were high in the early 1980 s and rebounded in the 2000 s } \\
\hline Charlotte, NC & $5.2 \%$ & $3.8 \%$ & $-35 \%$ & $-6 \%$ \\
\hline Chicago, IL & $6.3 \%$ & $4.9 \%$ & $-30 \%$ & $-24 \%$ \\
\hline Cincinnati, $\mathrm{OH}$ & $6.5 \%$ & $5.1 \%$ & $-14 \%$ & $-22 \%$ \\
\hline Cleveland, $\mathrm{OH}$ & $6.4 \%$ & $5.0 \%$ & $-14 \%$ & $-36 \%$ \\
\hline Columbus, $\mathrm{OH}$ & $6.2 \%$ & $4.8 \%$ & $-15 \%$ & $-23 \%$ \\
\hline Denver, CO & $5.1 \%$ & $3.7 \%$ & $-42 \%$ & $-28 \%$ \\
\hline Detroit, MI & $6.6 \%$ & $5.2 \%$ & $-11 \%$ & $-41 \%$ \\
\hline Fort Lauderdale, FL & $5.8 \%$ & $4.3 \%$ & $-42 \%$ & $-23 \%$ \\
\hline Indianapolis, IN & $6.0 \%$ & $4.5 \%$ & $-16 \%$ & $-25 \%$ \\
\hline Kansas City, KS & $5.7 \%$ & $4.2 \%$ & $-16 \%$ & $-7 \%$ \\
\hline Memphis, TN & $6.0 \%$ & $4.5 \%$ & $-29 \%$ & $-23 \%$ \\
\hline Miami, FL & $6.2 \%$ & $4.8 \%$ & $-15 \%$ & $-21 \%$ \\
\hline Milwaukee, MN & $7.0 \%$ & $5.7 \%$ & $-5 \%$ & $-33 \%$ \\
\hline Minneapolis, MN & $5.6 \%$ & $4.3 \%$ & $-10 \%$ & $-18 \%$ \\
\hline Orlando, FL & $5.9 \%$ & $4.4 \%$ & $-42 \%$ & $-23 \%$ \\
\hline Pittsburgh, PA & $7.1 \%$ & $5.7 \%$ & $-12 \%$ & $-18 \%$ \\
\hline St. Louis, MO & $6.1 \%$ & $4.7 \%$ & $-15 \%$ & $-7 \%$ \\
\hline Tampa, FL & $6.1 \%$ & $4.6 \%$ & $-18 \%$ & $-22 \%$ \\
\hline
\end{tabular}

Markets where house prices have declined since the early 1980 s and never fully rebounded:

$\begin{array}{lllll}\text { Fort Worth, TX } & 6.2 \% & 4.7 \% & -15 \% & -19 \% \\ \text { Houston, TX } & 6.7 \% & 5.2 \% & -38 \% & -20 \% \\ \text { New Orleans, LA } & 5.3 \% & 3.9 \% & -17 \% & -28 \% \\ \text { San Antonio, TX } & 6.9 \% & 5.4 \% & -42 \% & -23 \%\end{array}$




\section{Table 3}

\section{User Cost-Based Assessments of House Price Levels}

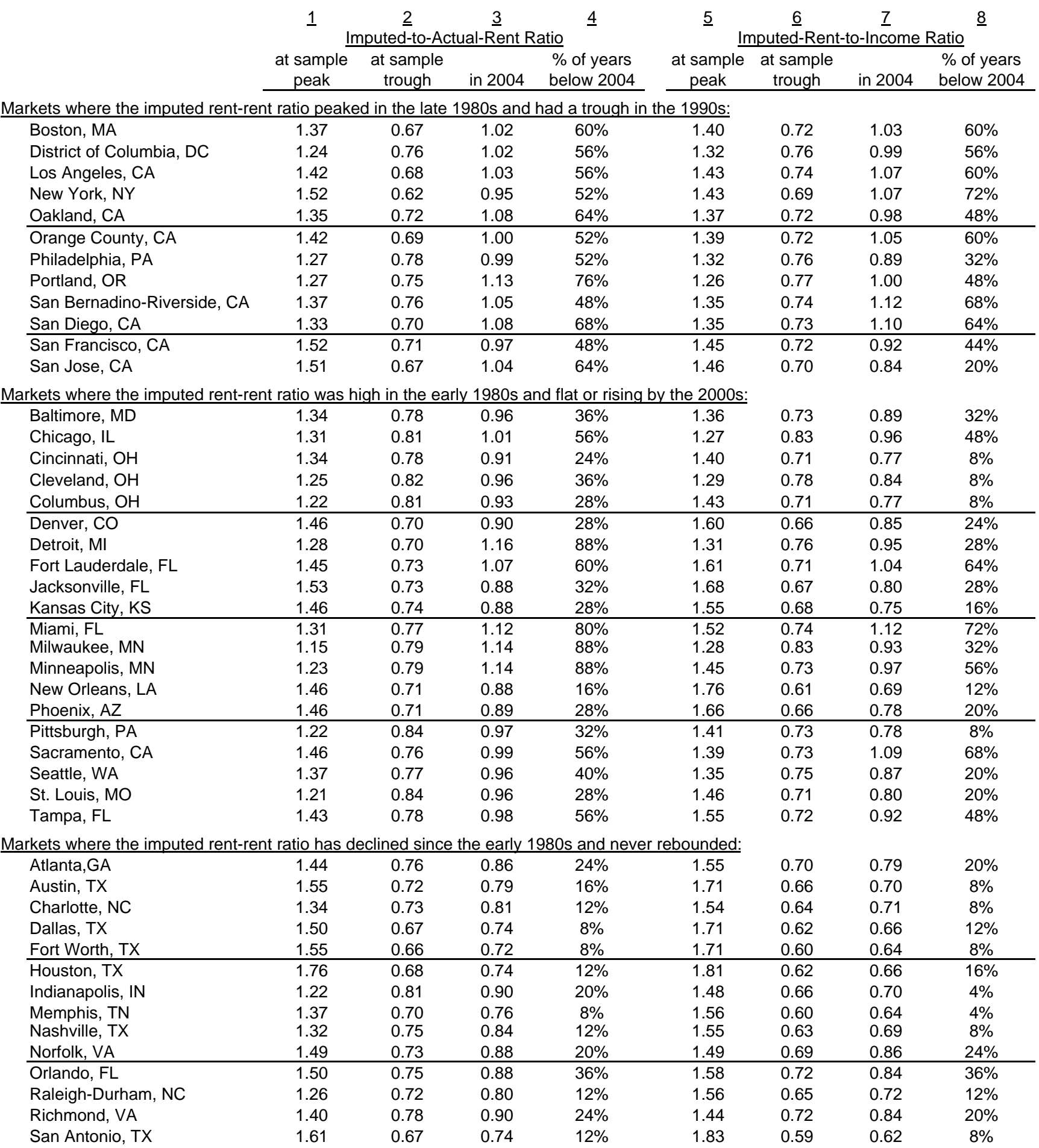

Notes: 24-year within-MSA average is normalized to 1.00. Values are not comparable across markets. 
Figure 1

Real US House Price Index, Price-to-Rent \& Price-to-Income Ratios

(Ratios normalized to 24-yr average)

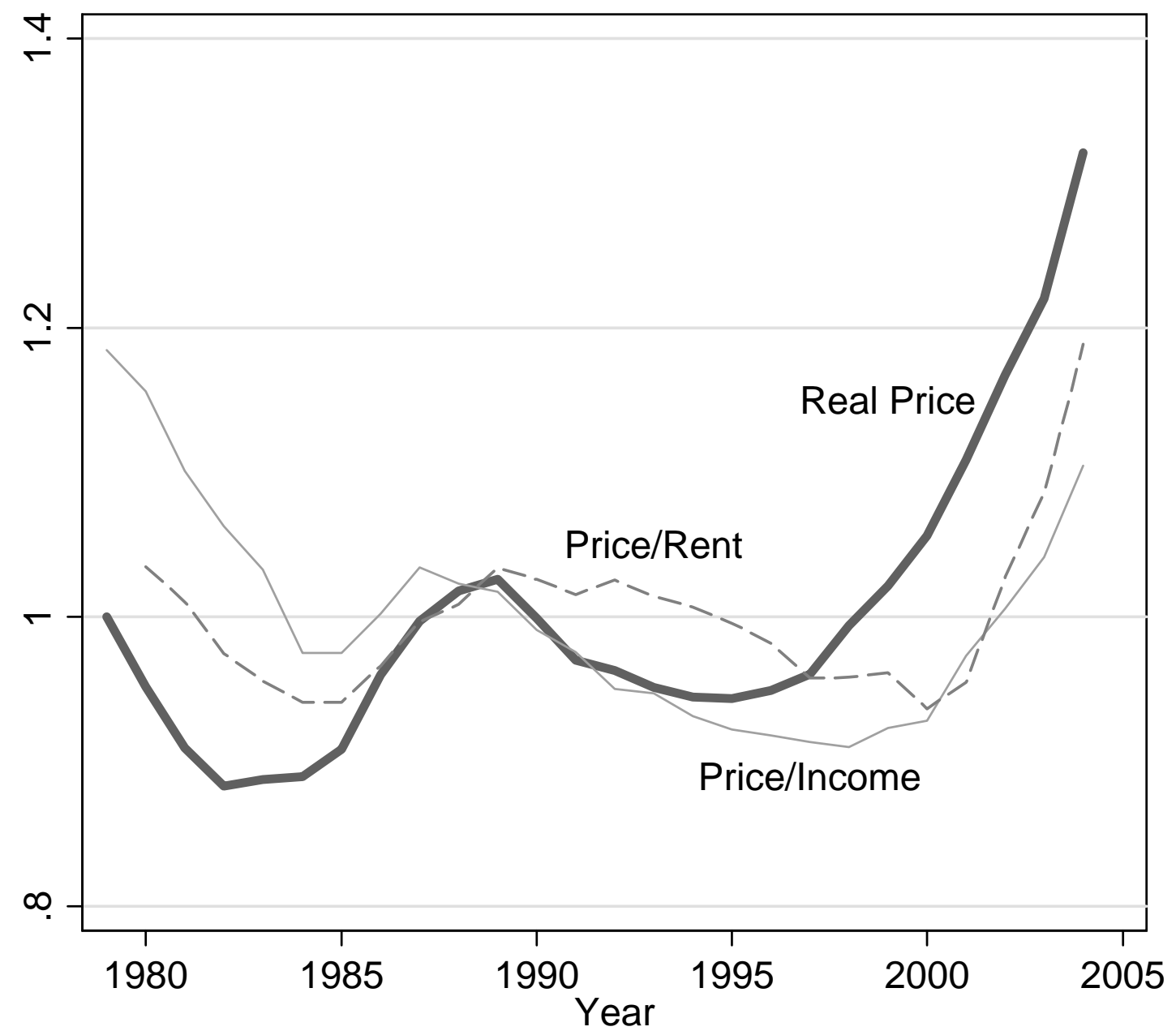

Source: OFHEO Price Index, REIS Inc., BEA, BLS CPI Index-All Urban Consumers 


\section{Figure 2}

Imputed-to-Actual-Rent Ratio vs Price-to-Rent Ratio

(Ratios normalized to 24-yr average)
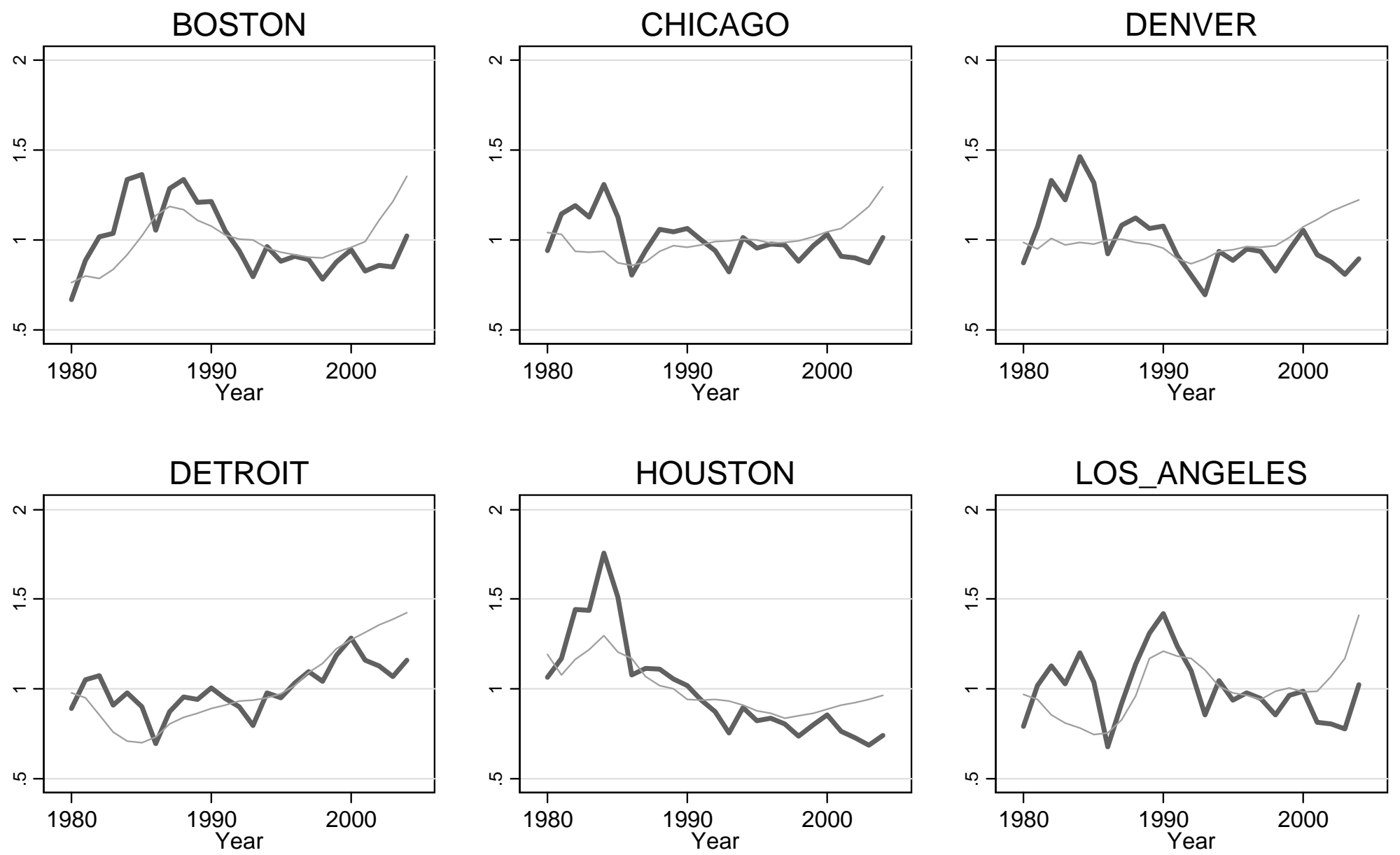

Source: Authors' Calculations 
Figure 2, Continued

Imputed-to-Actual-Rent Ratio vs Price-to-Rent Ratio

(Ratios normalized to 24-yr average)
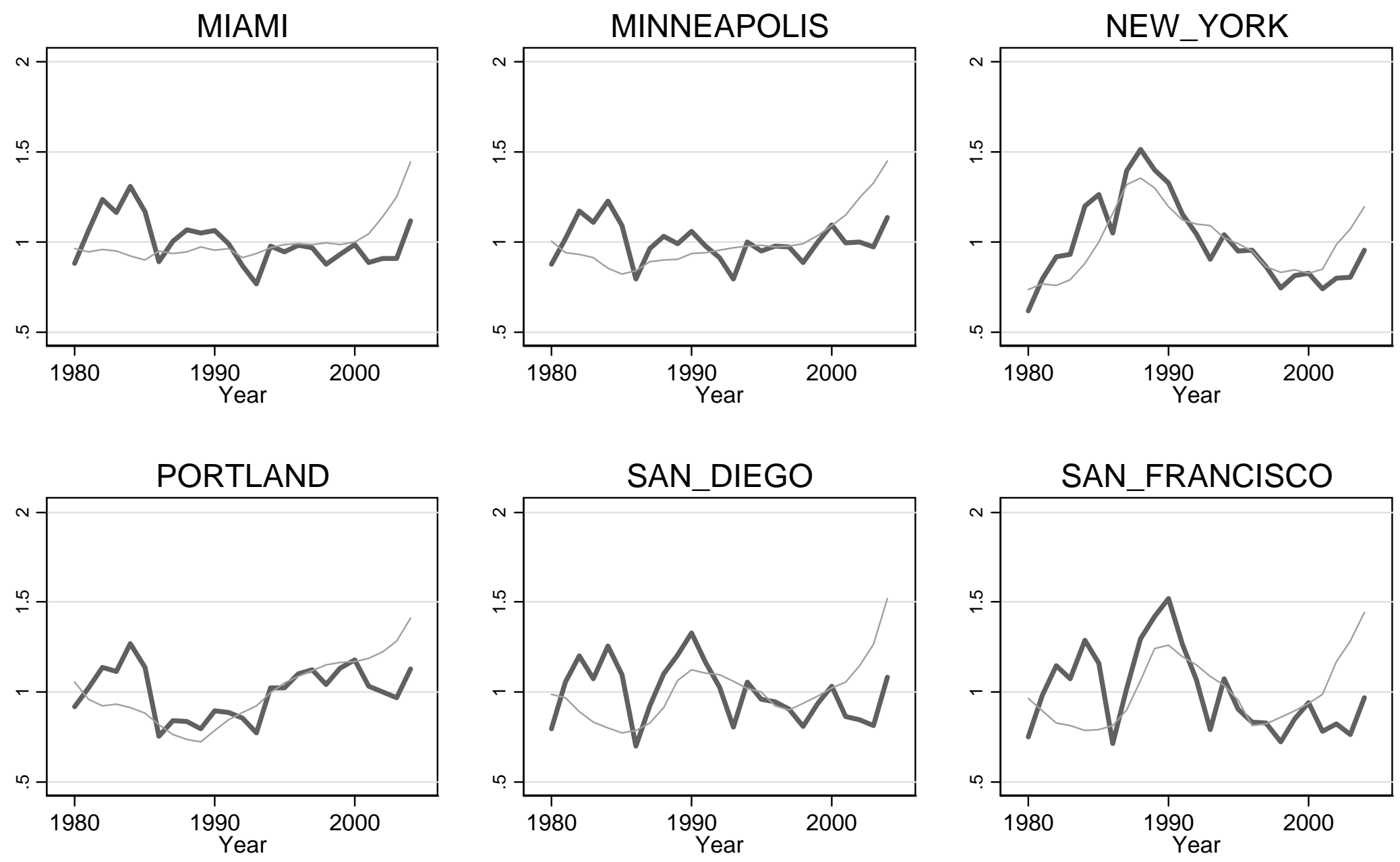

Source: Authors' Calculations 


\section{Figure 3}

\section{Real 10 Year Interest Rates}

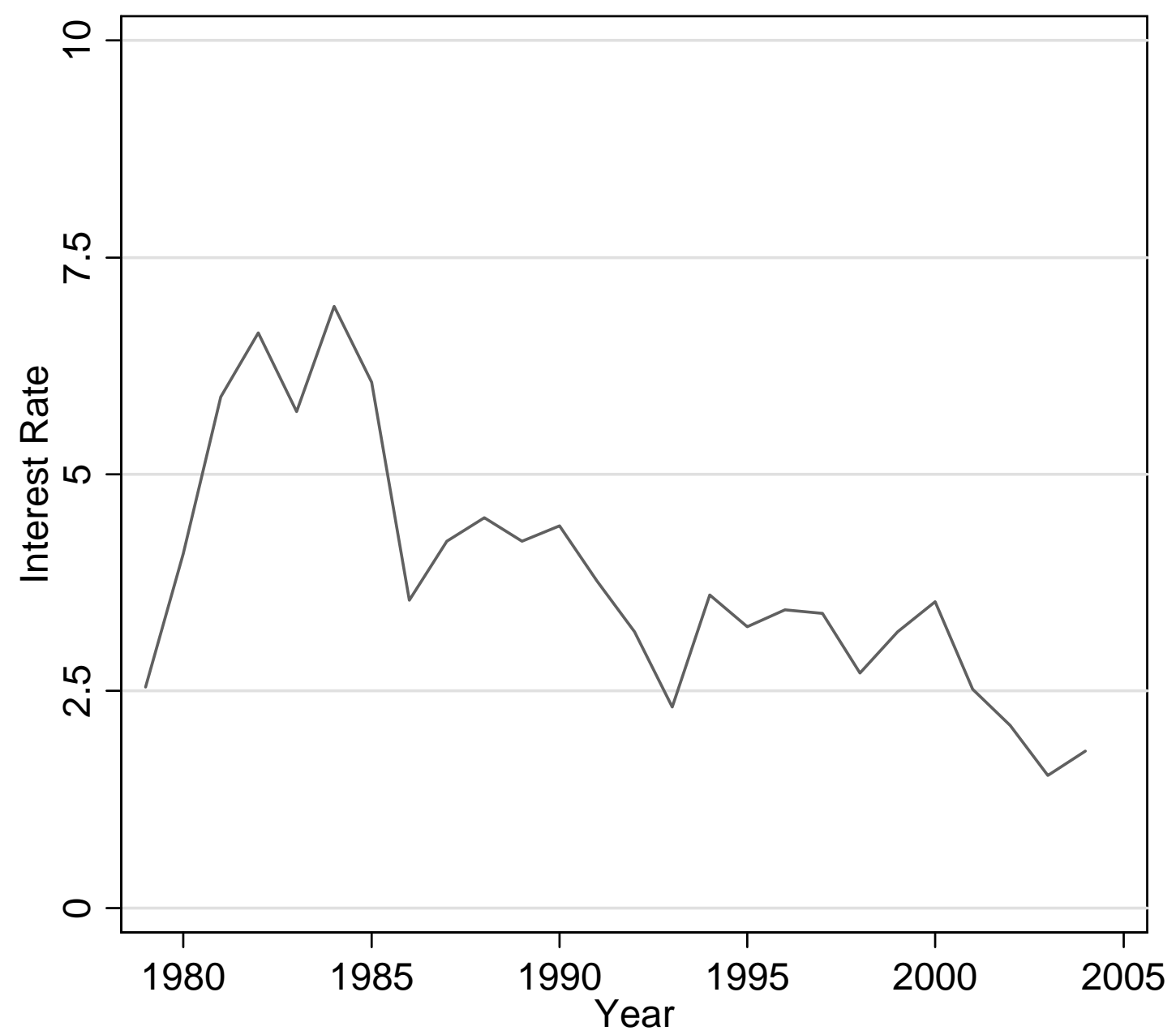

Source: Federal Reserve Bank H.15 Release, Federal Reserve Bank Livingston Survey: 10 yr expected inflation 


\section{Figure 4}

Imputed-Rent-to-Income Ratio vs. Price-to-Income Ratio

(Ratios normalized to 24-yr average)
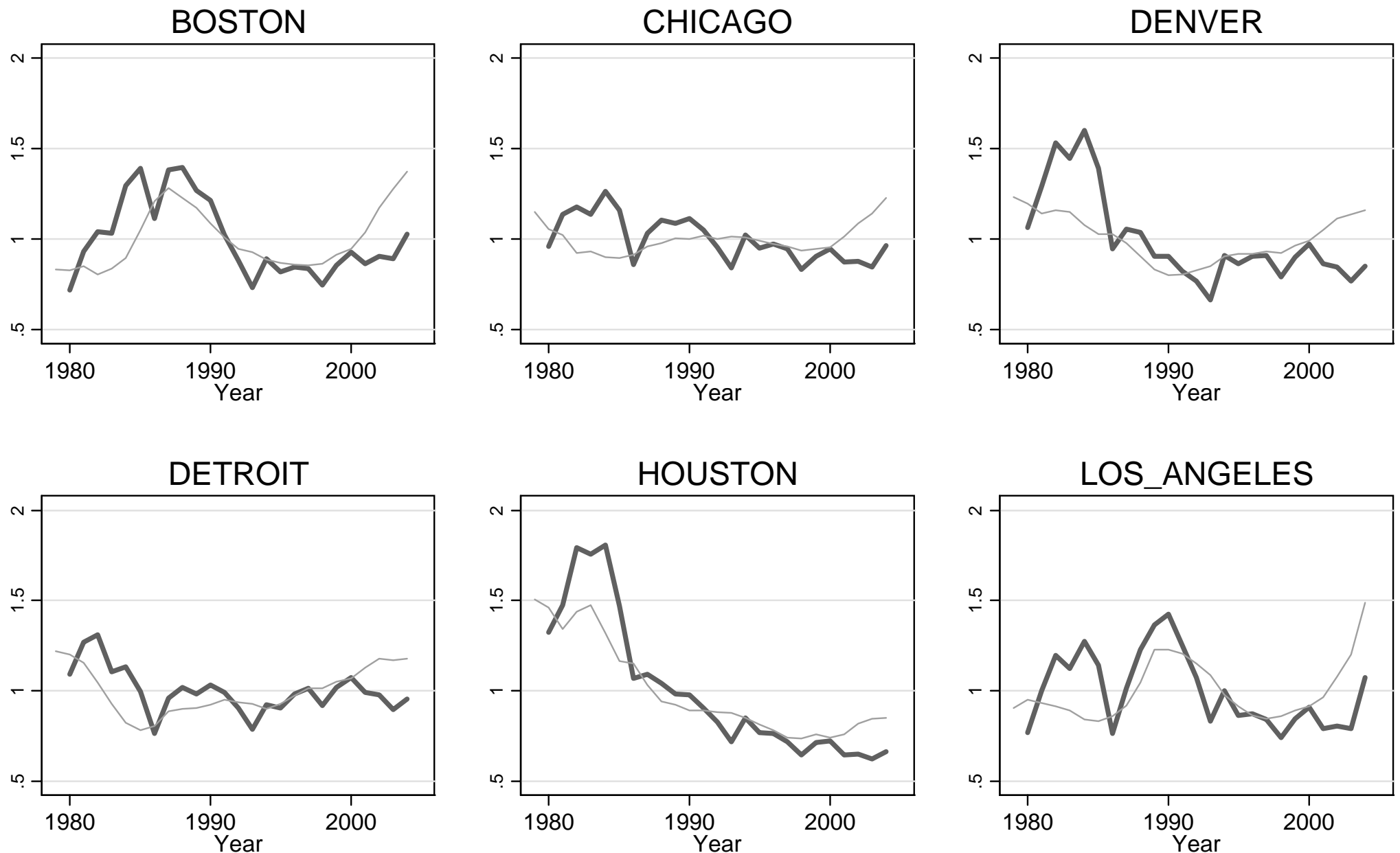

Source: Authors' Calculations 


\section{Figure 4, Continued}

Imputed-Rent-to-Income Ratio vs. Price-to-Income Ratio

(Ratios normalized to 24-yr average)
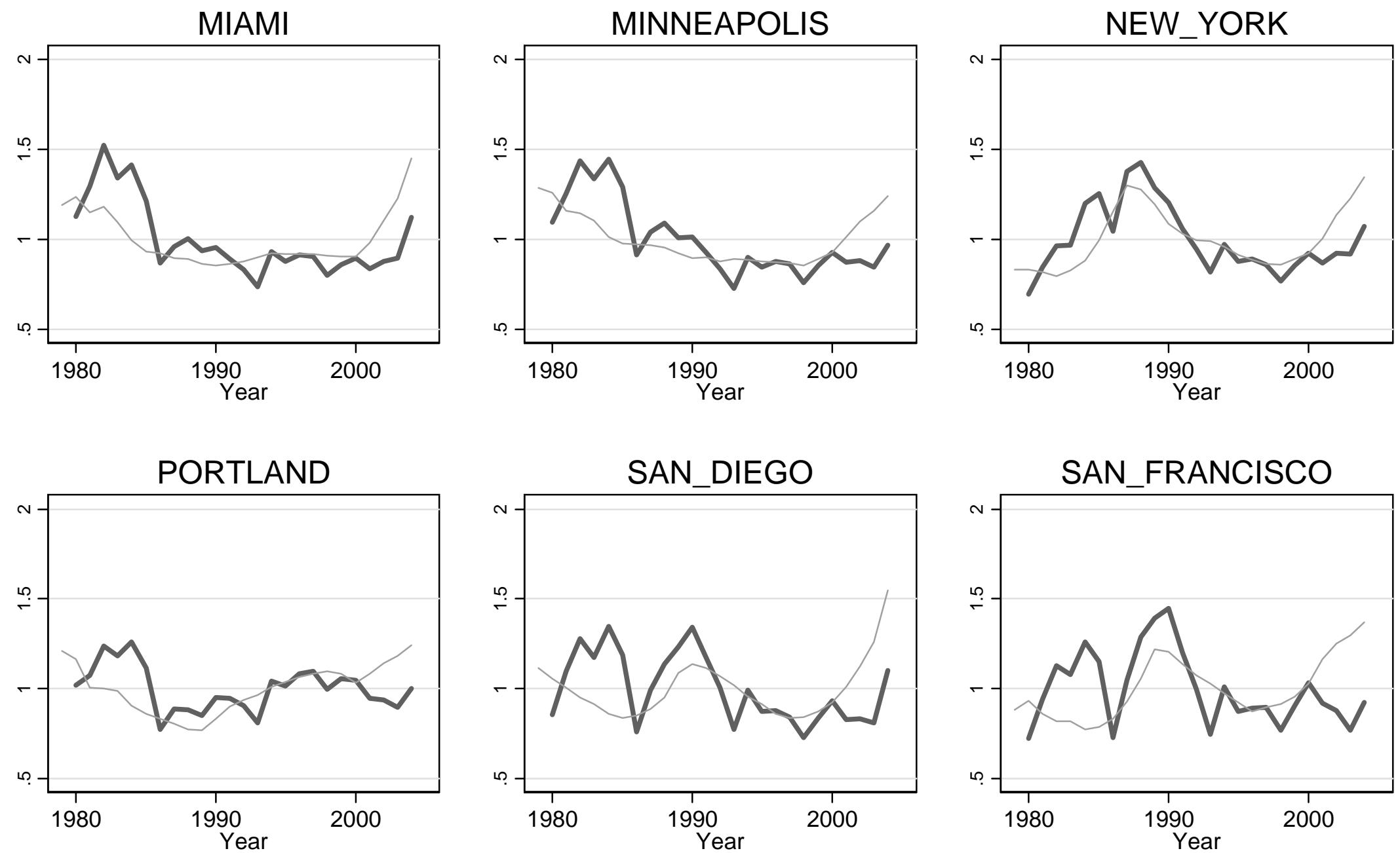

Source: Authors' Calculations 
Appendix Figure 1

Real House Price Index

(Index normalized to 24-year average)
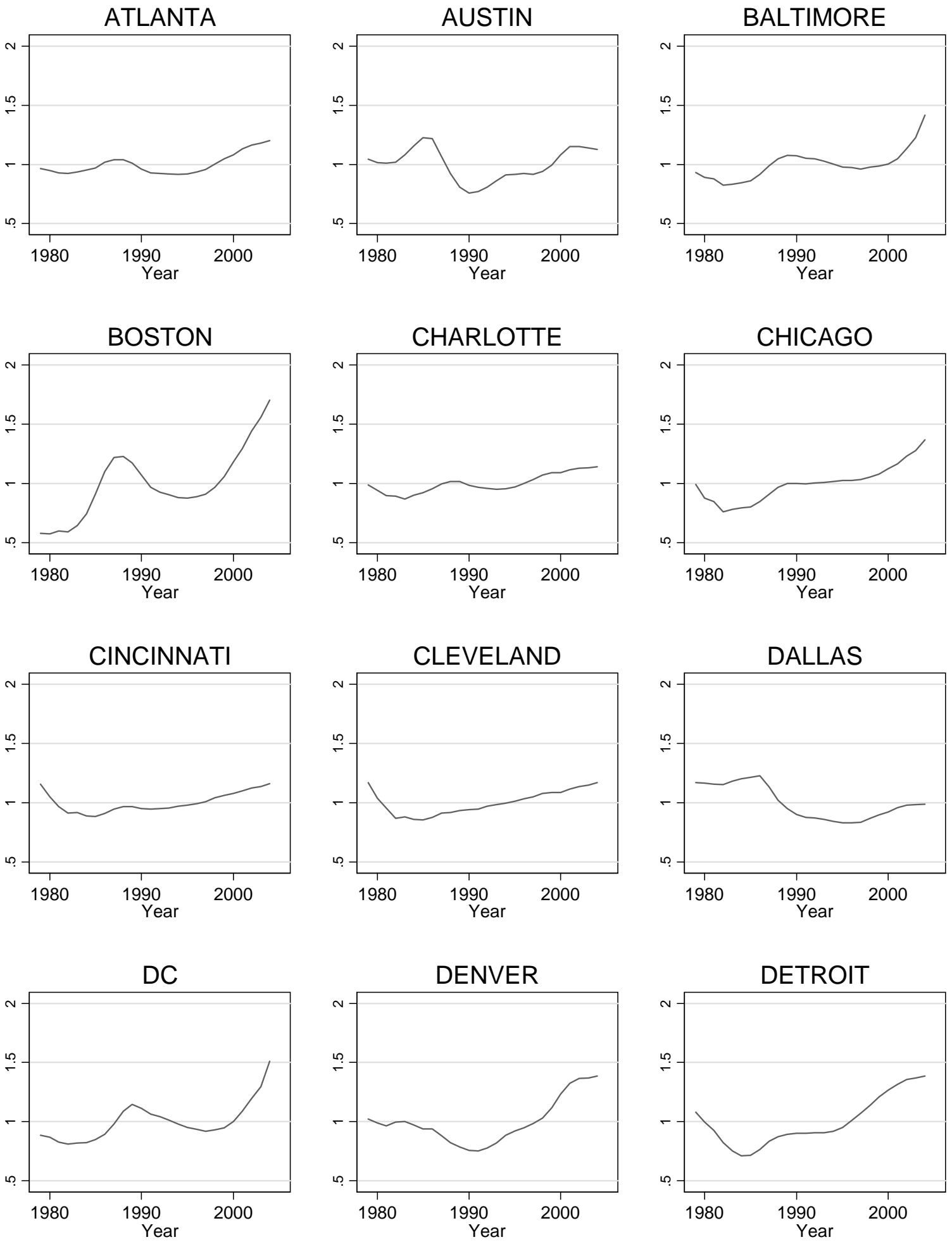


\section{Appendix Figure 1, continued \\ Real House Price Index}

(Index normalized to 24-year average)
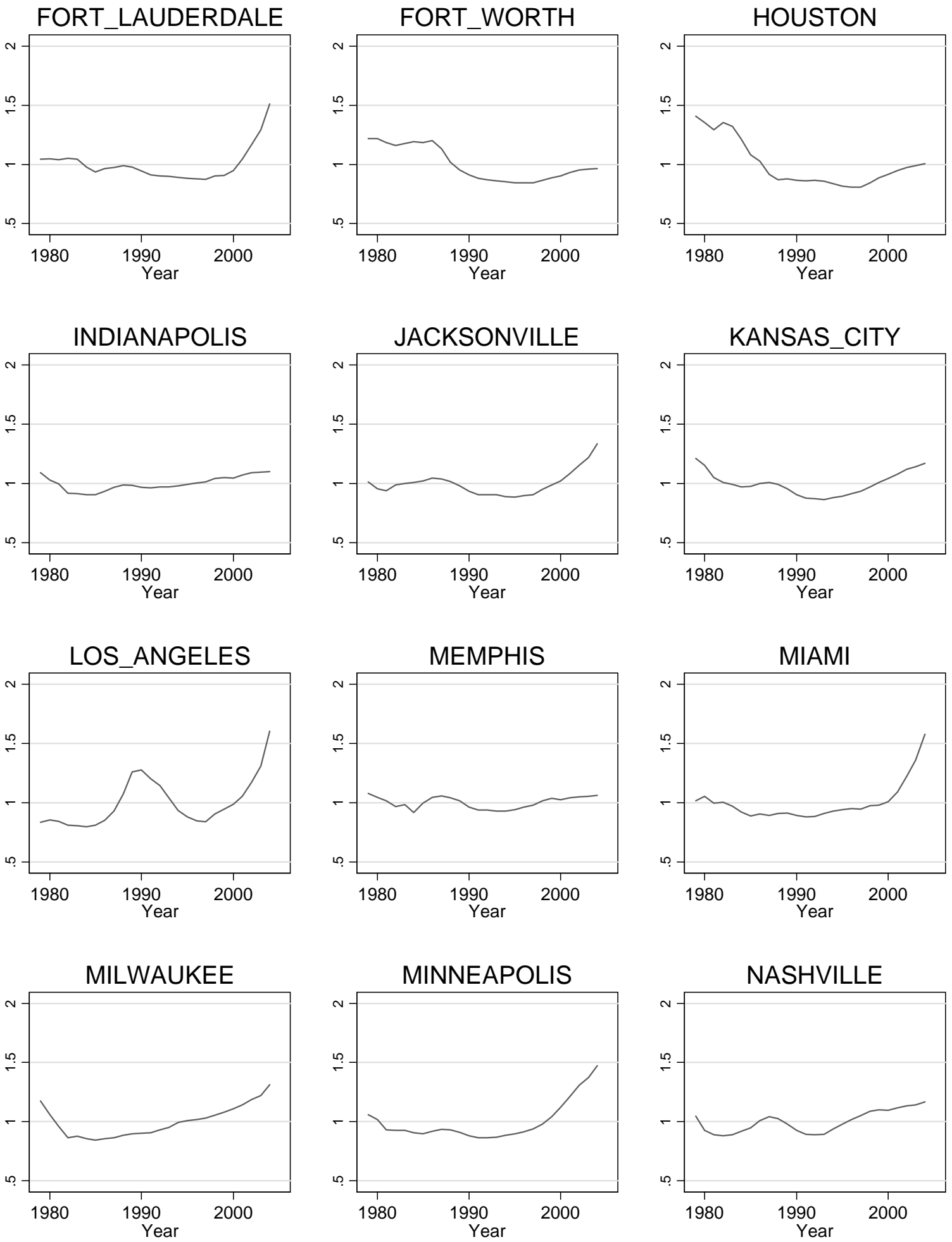


\section{Appendix Figure 1, Continued \\ Real House Price Index}

(Index normalized to 24-year average)
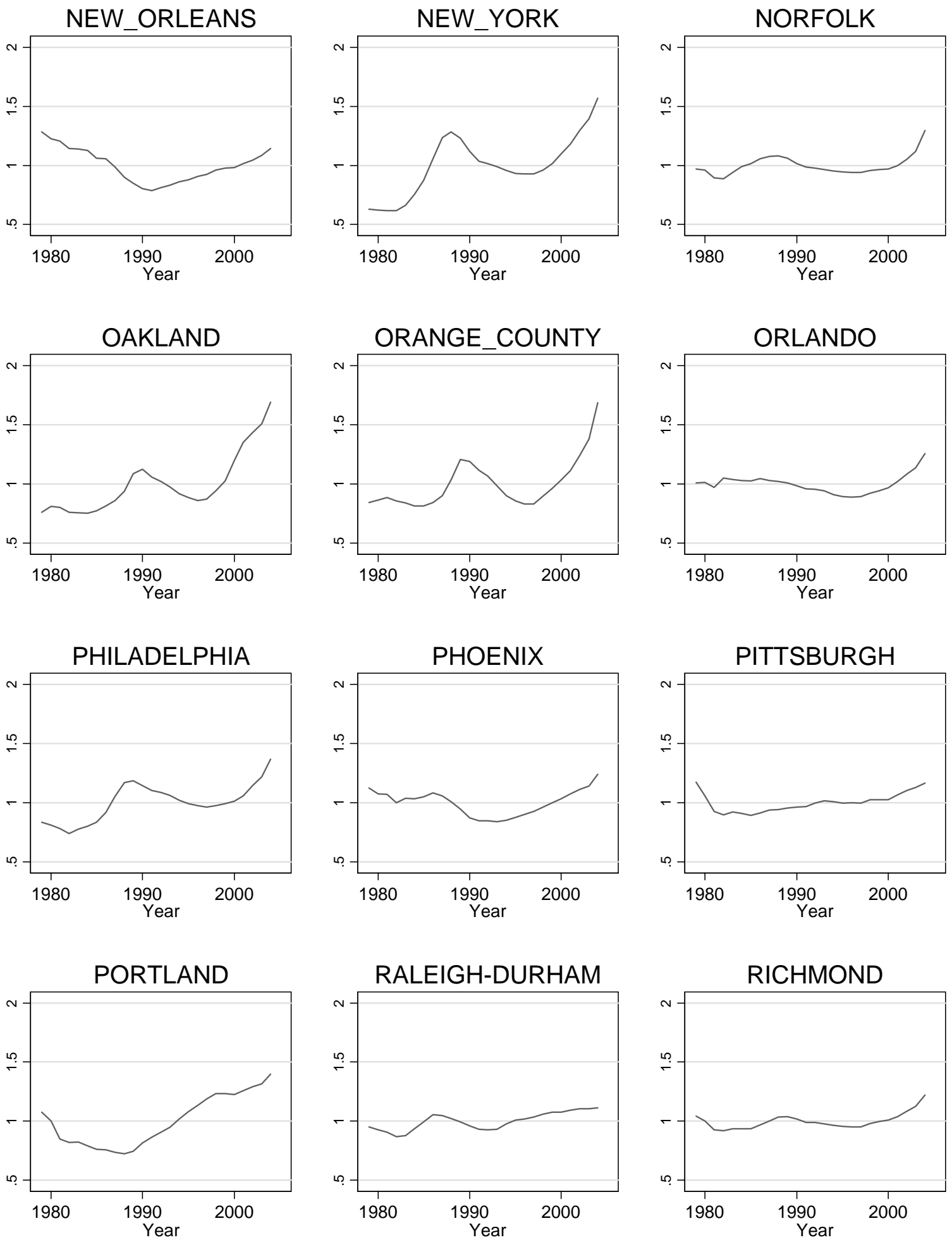


\section{Appendix Figure 1, Continued Real House Price Index}

(Index normalized to 24-year average)
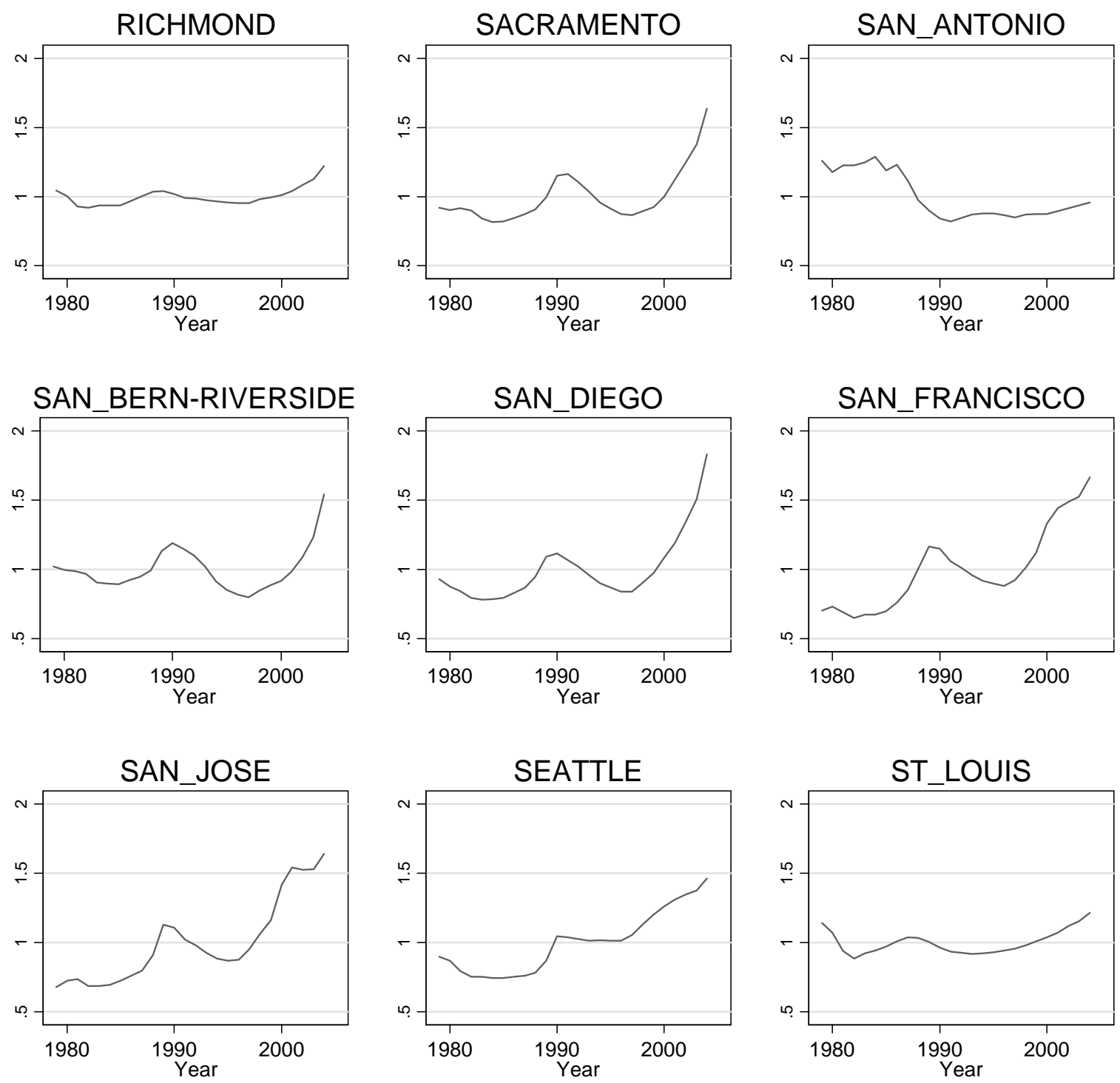

TAMPA

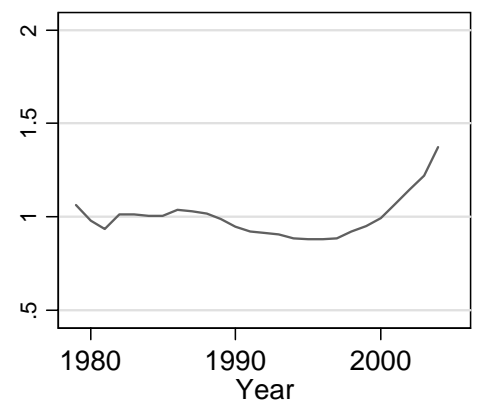

Source: OFHEO, BLS Consumer Price Index-All Urban Consumers 
Appendix Figure 2

Imputed-to-Actual-Rent Ratio vs Price-to-Rent Ratio

(Ratios normalized to 24-year average)
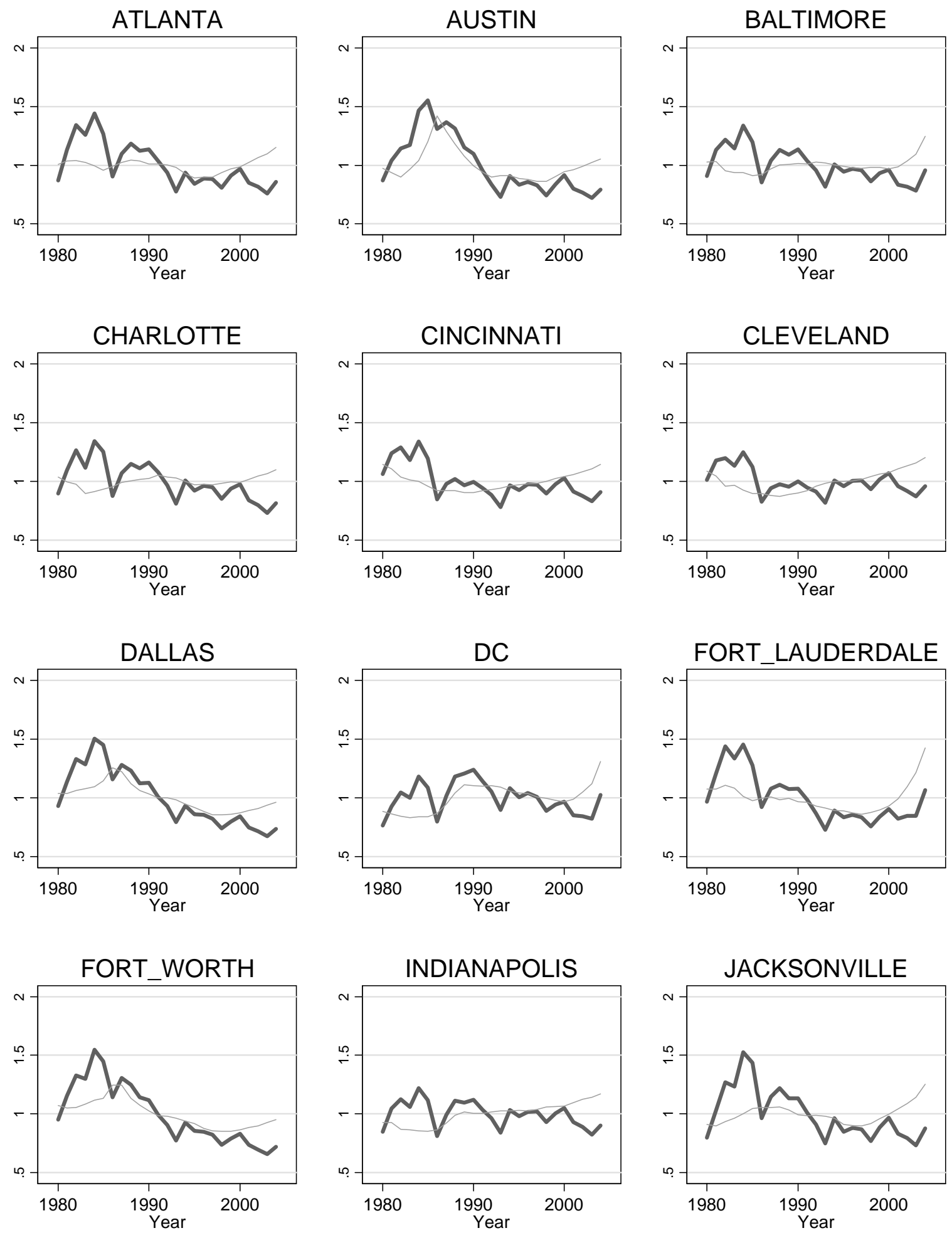


\section{Appendix Figure 2, Continued \\ Imputed-to-Actual-Rent Ratio vs Price-to-Rent Ratio}

(Ratios normalized to 24-year average)
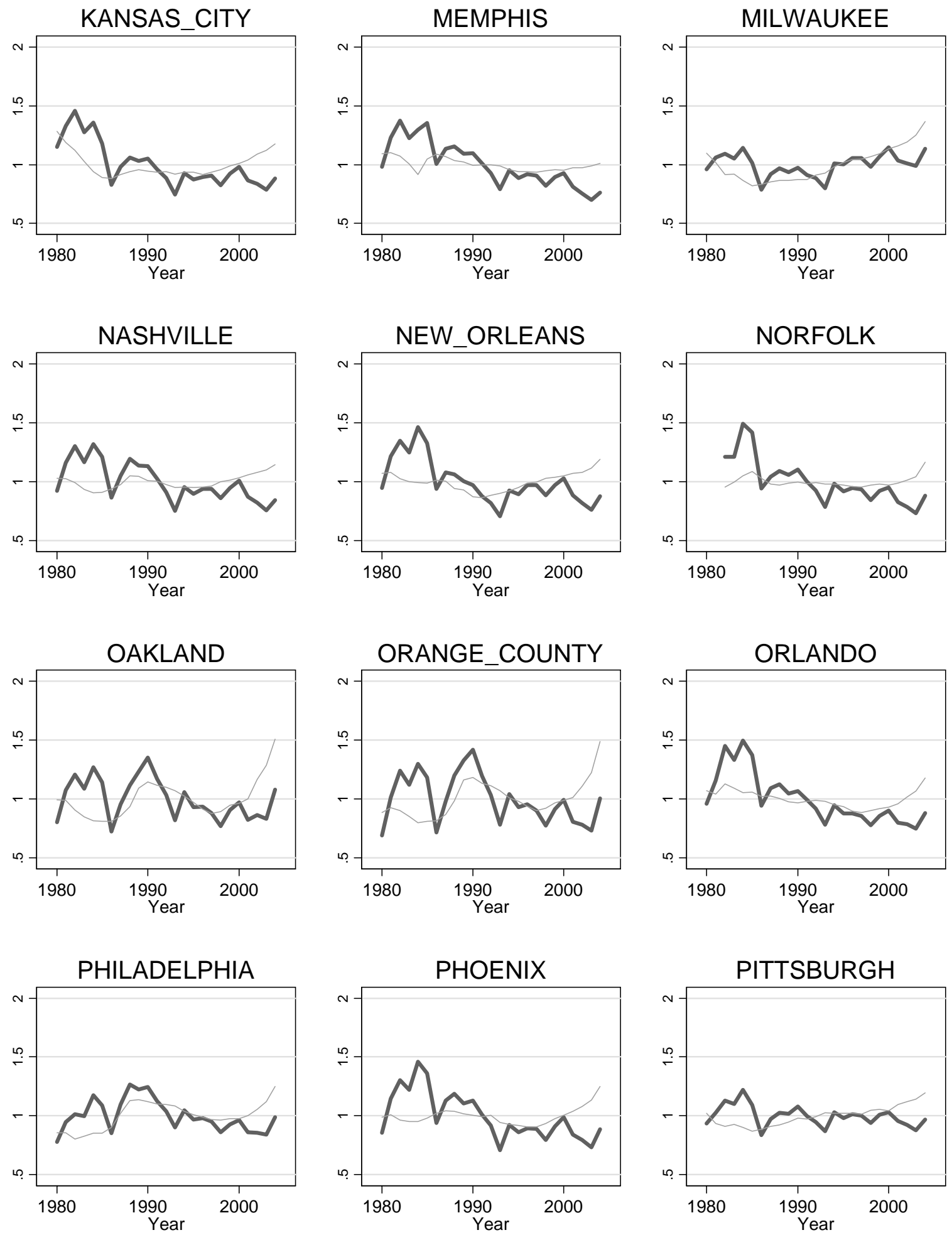

Imputed Rent/Actual Rent

Price/Actual Rent 


\section{Appendix Figure 2, Continued \\ Imputed-to-Actual-Rent Ratio vs Price-to-Rent Ratio}

(Ratios normalized to 24-year average)
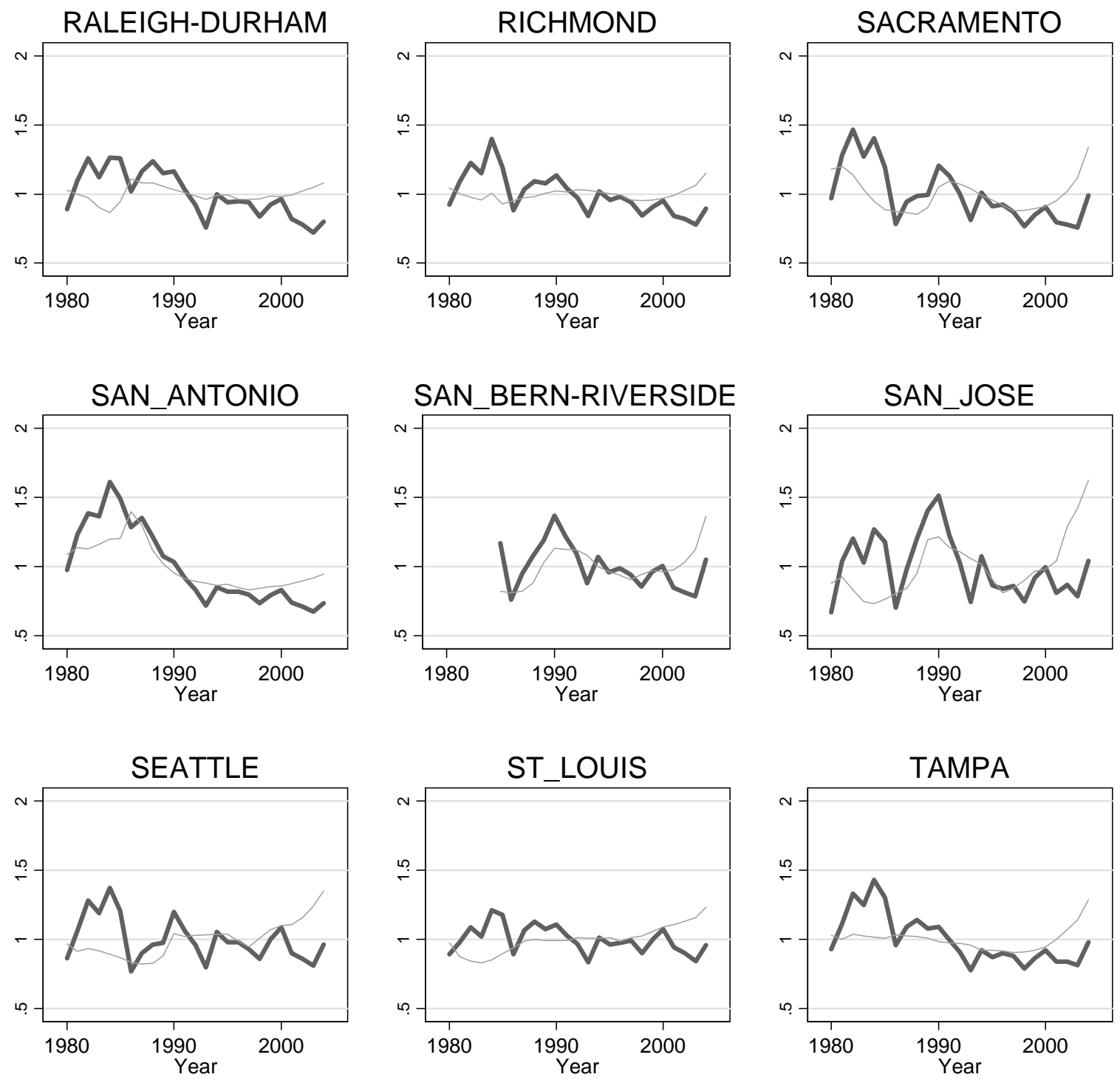

Imputed Rent/Actual Rent

Price/Actual Rent

Source: OFHEO, BLS Consumer Price Index-All Urban Consumers 


\section{Appendix Figure 3 \\ Imputed-Rent-to-Income Ratio vs. Price-to-Income Ratio \\ (Ratios normalized to 24-yr average)}
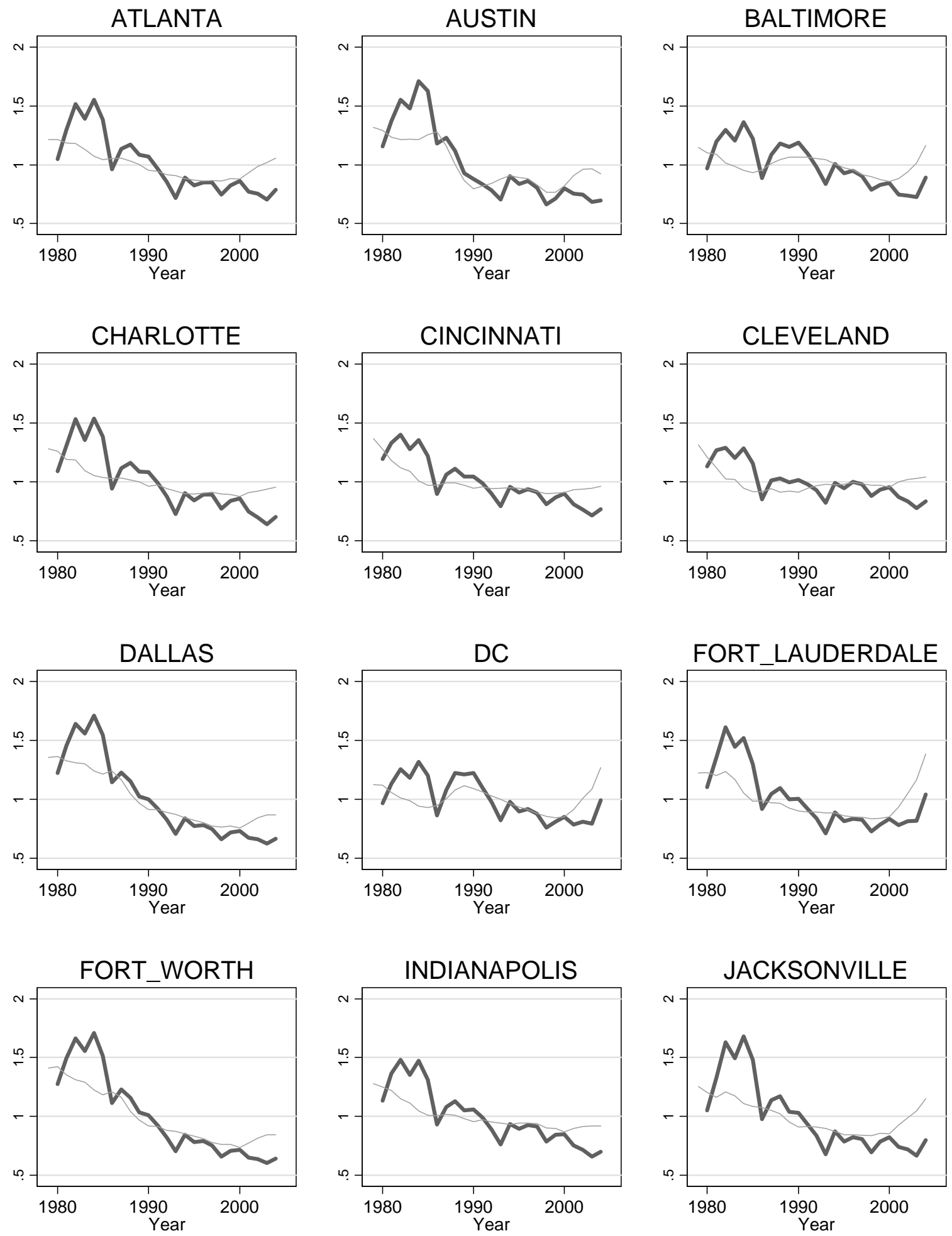


\section{Appendix Figure 3, Continued Imputed-Rent-to-Income Ratio vs. Price-to-Income Ratio (Ratios normalized to 24-yr average)}
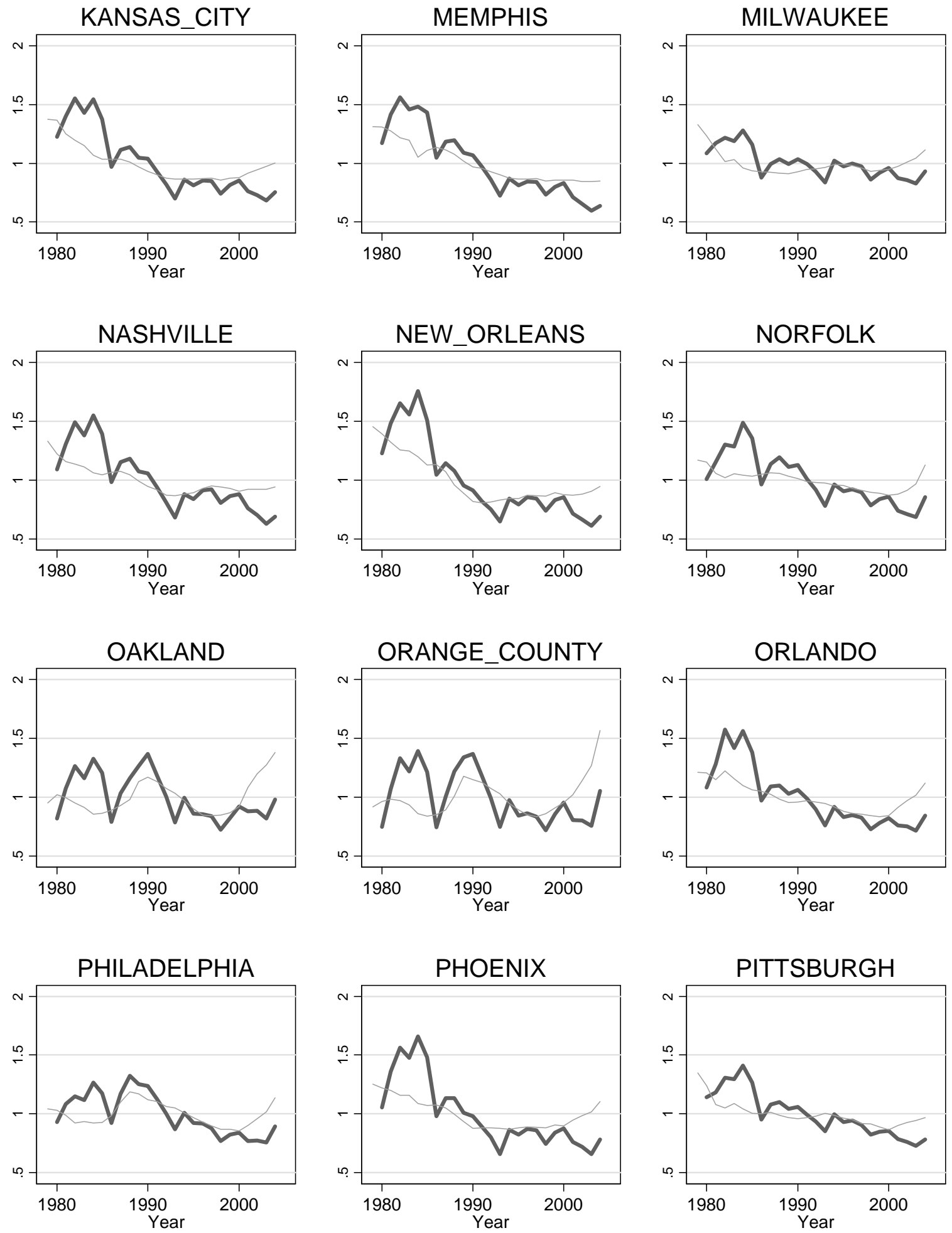


\section{Appendix Figure 3, Continued Imputed-Rent-to-Income Ratio vs. Price-to-Income Ratio (Ratios normalized to 24-yr average)}
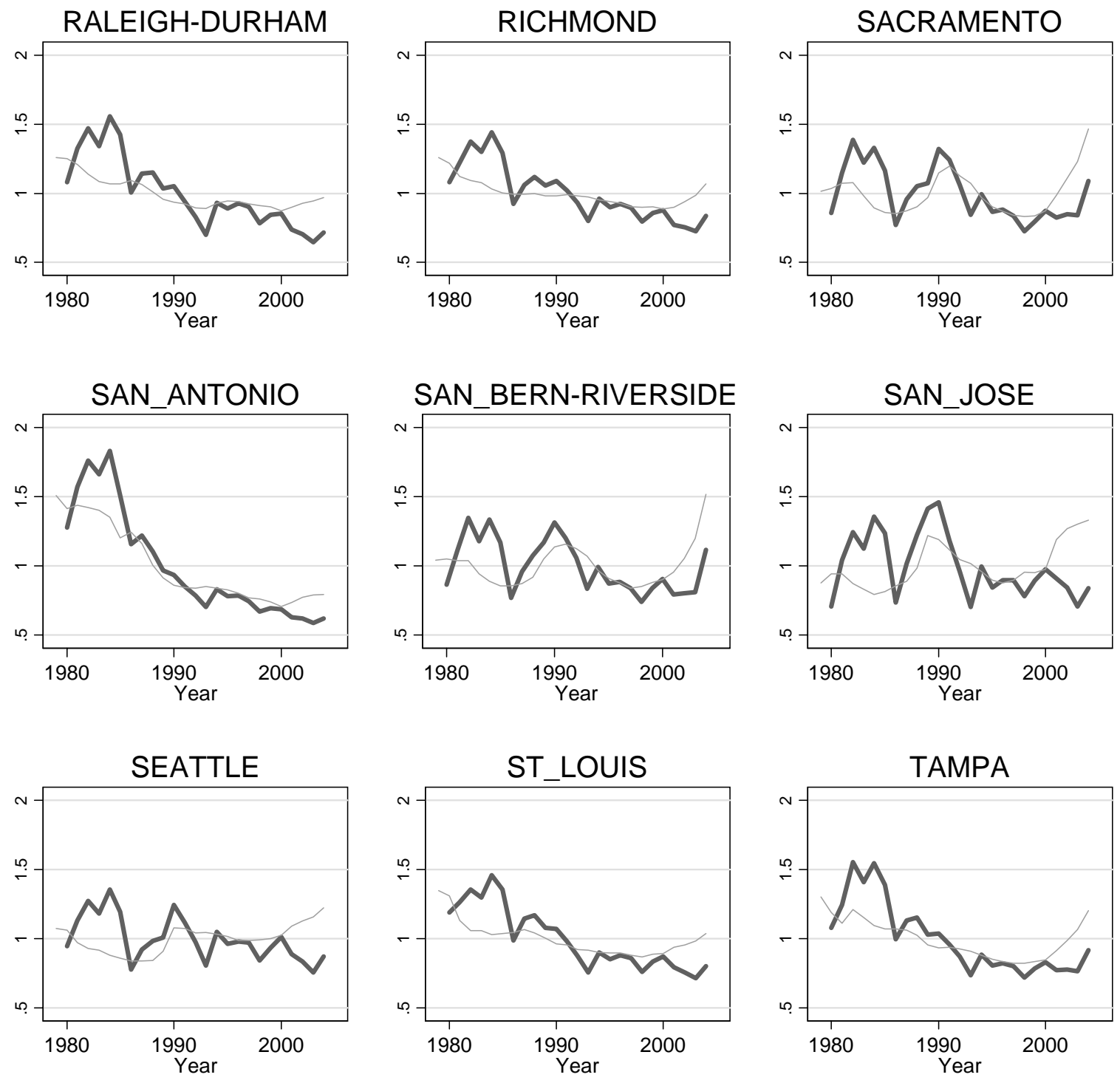

Imputed Rent/Income

Price/Income

Source: OFHEO, BLS Consumer Price Index-All Urban Consumers 